\title{
Regulatory dendritic cells: there is more than just immune activation
}

\section{Susanne V. Schmidt, Andrea C. Nino-Castro and Joachim L. Schultze*}

Genomics and Immunoregulation, LIMES-Institute, University of Bonn, Bonn, Germany

\section{Edited by:}

Manfred B. Lutz, University of

Wuerzburg, Germany

Reviewed by:

Francesca Granucci, University of Milano-Bicocca, Italy

Herbert Strobl, Medical University

Vienna, Austria

*Correspondence:

Joachim L. Schultze, Genomics and Immunoregulation, LIMES-Institute, University of Bonn, Carl-Troll-Str. 31, 53115 Bonn, Germany. e-mail:j.schultze@uni-bonn.de
The immune system exists in a delicate equilibrium between inflammatory responses and tolerance. This unique feature allows the immune system to recognize and respond to potential threats in a controlled but normally limited fashion thereby preventing a destructive overreaction against healthy tissues. While the adaptive immune system was the major research focus concerning activation vs. tolerance in the immune system more recent findings suggest that cells of the innate immune system are important players in the decision between effective immunity and induction of tolerance or immune inhibition. Among immune cells of the innate immune system dendritic cells (DCs) have a special function linking innate immune functions with the induction of adaptive immunity. DCs are the primary professional antigen presenting cells (APCs) initiating adaptive immune responses. They belong to the hematopoietic system and arise from $\mathrm{CD}_{4}{ }^{+}$stem cells in the bone marrow. Particularly in the murine system two major subgroups of DCs, namely myeloid DCs (mDCs) and plasmacytoid DCs (pDCs) can be distinguished. DCs are important mediators of innate and adaptive immunity mostly due to their remarkable capacity to present processed antigens via major histocompatibility complexes (MHC) to $T$ cells and $B$ cells in secondary lymphoid organs. A large body of literature has been accumulated during the last two decades describing which role DCs play during activation of $\mathrm{T}$ cell responses but also during the establishment and maintenance of central tolerance (Steinman et al., 2003). While the concept of peripheral tolerance has been clearly established during the last years, the role of different sets of DCs and their particular molecular mechanisms of immune deviation has not yet fully been appreciated. In this review we summarize accumulating evidence about the role of regulatory DCs in situations where the balance between tolerance and immunogenicity has been altered leading to pathologic conditions such as chronic inflammation or malignancies.

\section{MAJOR FUNCTIONAL STATES OF DCs DURING IMMUNE ACTIVATION}

A major focus of research into DC biology was built on observations during immune activation. DCs are a heterogeneous cell population that can acquire diverse maturation states and functions. Intensive studies of DC development in mice lead to the conception that DCs derive under homeostatic conditions from hematopoietic $\mathrm{CD} 34^{+}$stem cells in the bone marrow and potentially in the intestinal lamina propria (Bogunovic et al., 2009) while monocyte-derived DCs have been described under inflammatory conditions (Cheong et al., 2010). Also, human CD14 ${ }^{+}$ $\mathrm{CD} 34^{+}$PBMCs were described to give rise to DCs by the influence of platelet endothelial cell adhesion molecule-1 (Ferrero et al., 1998). Myeloid precursor cells in the bone marrow give rise to common DC precursor cells with the ability to proliferate and relocate to bone marrow, spleen, and lymph nodes. The major function of DCs has been attributed to the initiation steps of immune activation leading to protection of the individual against invading pathogens and the immune surveillance against transformed cells.
At least two categories of DCs have been described for the mammalian immune system (Banchereau et al., 2000). Myeloid DCs (mDCs) also called conventional DCs have a strong capability to capture antigens which enables them to stimulate $\mathrm{T}$ cells. These major antigen presenting and activating cells comprise a very heterogeneous group of cells expressing high levels of MHC class II and integrin CD11c on their cell surface, but also other adhesion molecules, like LFA-1 (CD11a), LFA-3 (CD58), ICAM-1 (CD54), ICAM-2 (CD50), and ICAM-3 (CD102). The costimulatory molecules $\mathrm{CD} 80$ and $\mathrm{CD} 86$ have been established as hallmarks of DC maturation during an immune response with CD86 being expressed at early stages of maturation, while CD80 (and also CD83) become upregulated in mature DCs. The Langerhans cells of the skin are one major representative subgroup of the mDCs continuum. Murine mDCs are characterized by the expression of CD11b and CD11c and are generated in vitro by stimulation of bone marrow progenitor cells while in the human, DCs are often generated from peripheral blood monocytes using GM-CSF and IL-4 (Sallusto and Lanzavecchia, 1994). 
A second group of DCs are plasmacytoid DCs (pDCs) that are found in circulation and in peripheral lymphoid organs. In comparison to other APC the capacity of pDCs to present antigens is rather low since immature pDCs express only low levels of MHC-II or other costimulatory molecules. Upon activation they secrete large amounts of IFN $\alpha$ and IFN $\beta$ (Cella et al., 1999; Siegal et al., 1999). Infection with RNA- and DNA-viruses induces IFN-related immune responses in $\mathrm{pDCs}$ human and mice after the recognition of viral genomes via pattern recognition receptors (PRR) such as toll-like receptors (TLRs) 7 and 9 (Lund et al., 2003; Di Domizio et al., 2009; Swiecki and Colonna, 2010). Characterization via surface receptors revealed that $\mathrm{pDCs}$ do not express markers commonly present on human mDCs such as CD11c, but express instead the interleukin 3 receptor (CD123) and exclusively the type II c-type lectin BDCA-2 (CD303) which is involved in the presentation of antigens to $\mathrm{T}$ cells (Dzionek et al., 2001). In contrast to human pDCs murine pDCs are characterized by the expression of CD11c, B220, Gr-1, CD45RA, Ly49Q, BST2, and Siglec-H (Gehrie et al., 2011). It is assumed that these cells play a major role in anti-viral immune responses since they produce high amounts of IFN $\alpha$ after viral infection.

A third group named follicular DCs (fDCs) can be found in the germinal centers of lymph nodes presenting antigens to B cells to maintain immune memory. fDCs extracted out of human tonsils have been found to express the surface receptors CD21, CD23 CD35, and cell cycle markers DRC-1, Ki-M4 or DR53 (Kim et al., 1994). Interestingly, in contrast to $\mathrm{pDCs}$ and $\mathrm{mDCs} \mathrm{fDCs}$ share some common antigens such as 3C8 with fibroblasts suggesting that these cells share some molecular programs (Lindhout et al., 1999; Lee and Choe, 2003; Vinuesa et al., 2010).

Immature DCs patrol via the blood systems throughout the body and can invade peripheral tissues to take up antigens from infected or dying cells via macropinocytosis, phagocytosis, and endocytosis (Steinman et al., 1999). Migration of DCs from peripheral tissues to lymph nodes also occurs under steady state conditions in absence of infection and might contribute to tolerance induction. Receptors of the C-type lectin family like DEC205, DCIR or the mannose receptor (CD206) directly capture antigens and direct them to antigen processing antigen processing machinery in the endosomal compartment or the cytosol (Villadangos and Schnorrer, 2007). The expression of PRR including TLRs, NOD-like receptors and RIG-like helicases by DCs enables these immune cells to recognize bacterial (e.g., LPS) or viral (e.g., single-stranded RNA) compounds, so called pathogen associated molecular patterns (PAMPs) (Janeway and Medzhitov, 2002). More recently, it was shown that DCs also recognize intracellular host factors released to the extracellular space after cell damage, called damage associated molecular patterns (DAMPs) like HMGB1 or S100A/B proteins. mDCs are found to express TLR1, TRL2, TRL4, TLR5, and TLR8, while pDCs express TLR-7 and TLR-9. After activation of the TLRsignaling cascade via the adaptor molecules MYD88 and TRIF pro-inflammatory transcription factors like NFKB and several interferon regulating factors (IRFs) are activated and lead maturation of DCs and to the expression of immune activating mediators (Hemmi and Akira, 2005). A central contribution to immune activation is the presentation of processed antigens via major histocompatibility complexes (MHC) in presence of costimulatory molecules on the cell surface of DCs to T cells and $\mathrm{B}$ cells in secondary lymphoid organs. The transport of peptideloaded MHC molecules to the cell surface is accompanied by an increased expression of costimulatory molecules like CD80 and CD86. Other typical maturation marker on matured human and mice DCs are elevated levels of HLA-DR, CD40, CD80, CD1a, and CD54 (Reis e Sousa, 2006). The activation of signaling cascades downstream of PRRs also induces DC migration to afferent lymph nodes to present antigens to $\mathrm{T}$ cells and $\mathrm{B}$ cells (Hemmi and Akira, 2005) which is mediated by the chemokine and homing receptor CCR7 along a gradient of the two chemokines CCL19 Epstein-Barr virus-induced molecule-1 ligand chemokine (ELC), and CCL21 Secondary lymphoid tissue chemokine (SLC) (Sanchez-Sanchez et al., 2004; Riol-Blanco et al., 2005). Mature mDCs secrete high amounts of inflammatory cytokines such as IL-12, necessary for the differentiation of naïve T cells toward certain $\mathrm{T}$ helper cell subsets (Figure 1). In principle, DCs unite at least four different signals in the immune synapse. One activation signal is established by the presentation of processed antigens via MHC molecules that interact with the $\mathrm{T}$ cell receptor complex. The binding of the adhesion molecule ICAM- 1 with LFA- 1 on the $\mathrm{T}$ cell surface strengthens the contact of both immune cells and the so-called signal two is established by the interaction between costimulatory molecules CD80/CD86 expressed on matured DCs with CD28 on T cells. Finally, an interaction between CD40 on DCs and CD40L on T cells is established leading to increased IL12 production of DCs. The elevated levels of IL-12 finally lead to a $\mathrm{T}_{\mathrm{H}} 1$ polarization and secretion of the cytokine IFN $\gamma$ which is necessary for the recruitment of macrophages and cytotoxic $\mathrm{T}$ cells. While there is no doubt about the exceptional role of DCs during immune activation, more and more evidence has been accumulated demonstrating that these specialized cells can also exert regulatory functions.

\section{DEFINING REGULATORY DENDRITIC CELLS}

While activation and maturation of dendritic cells (DCs) and their immunostimulatory capacity are clearly linked to a distinct phenotypic change with upregulation of MHC molecules, costimulatory molecules, and the enhanced production of inflammatory cytokines, this is less clear for DCs exerting regulatory functions. Initially, regulatory, inhibitory or even tolerance-inducing capabilities were assigned to immature DCs, a differentiation state prior maturation. It has been a common view that DCs exist in an immature and a mature state. Initial experiments demonstrated that immature DCs can induce tolerance, which was explained by the finding that immature DCs process and present antigens in the absence of costimulation, leading to $\mathrm{T}$ cell anergy and deletion (Jonuleit et al., 2000; Lutz et al., 2000; Reis e Sousa, 2006; Manicassamy and Pulendran, 2011). However, during the last years, fully matured DCs with regulatory functions have been observed in numerous distinct settings suggesting that regulatory $\mathrm{DCs}\left(\mathrm{DC}_{\mathrm{reg}}\right)$ are a functional state rather than a unique subpopulation defined by phenotypical markers. For example, in a murine colitis model CD103 ${ }^{+}$DCs acquire immune-activating functions under inflammatory conditions and express pro-inflammatory cytokines (Laffont et al., 


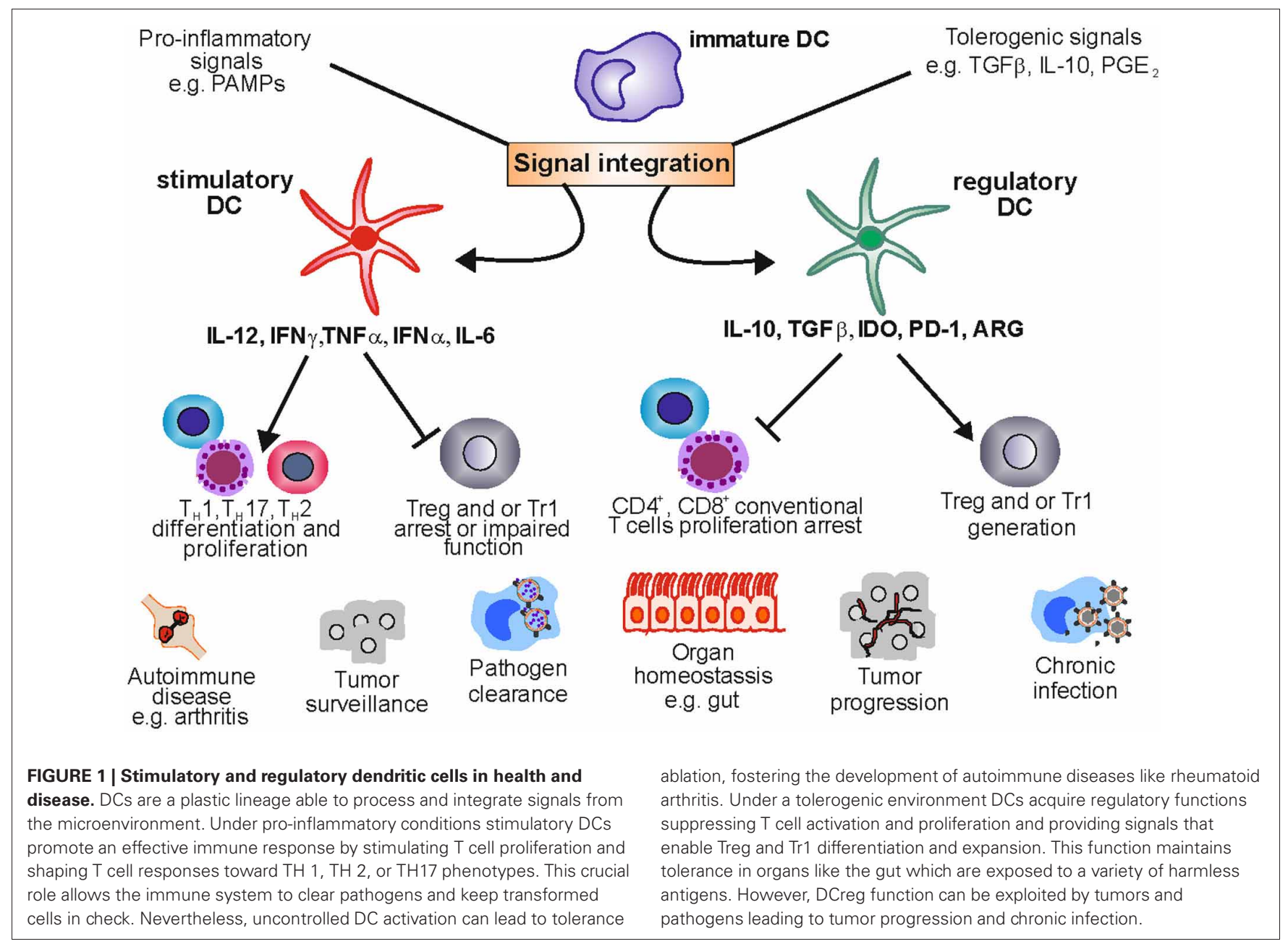

2010). However, under steady state conditions CD103 ${ }^{+}$DCs in the gut where shown to be strong inducers of $\mathrm{T}$ cell tolerance, which was manifested by their capacity to induce Foxp $3^{+} \mathrm{T}_{\text {reg }}$ from $\mathrm{CD}^{+}$naïve precursors (Del Rio et al., 2010; Scott et al., 2011). A similar situation was observed in the liver where low numbers of $\mathrm{pDCs}$ are associated with viral persistence during chronic hepatitis $\mathrm{C}$ infection while elevated numbers of highly active DCs are associated with pathogen clearance (Lai et al., 2007). At the same time resident $\mathrm{pDCs}$ in the liver promote immune regulation through various mechanisms (Matta et al., 2012). Yet another example is the coexistence of DCs with stimulatory and regulatory functions in the tumor microenvironment. Depending on the expression of immunomodulatory factors and cytokines in the tumor, $\mathrm{DC}_{\text {reg }}$ together with other immunoregulatory cells can be recruited to the tumor environment (Shurin et al., 2011; Gabrilovich et al., 2012). Further evidence for the existence of fully matured $\mathrm{DC}_{\mathrm{reg}}$ came from a murine asthma model, demonstrating that fully matured DCs expressing high levels of costimulatory molecules stimulated $\mathrm{T}_{\text {reg }}$ development via an IL-10 depending mechanism (Akbari et al., 2001). In humans, monocyte-derived DC stimulated with prostaglandin E2 $\left(\mathrm{PGE}_{2}\right)$ and TNF $\alpha$ exhibit a fully mature phenotype characterized by high expression of costimulatory molecules and pro-inflammatory cytokines, yet they suppress $\mathrm{T}$ cell activation via a combination of factors like indoleamine 2,3 deoxygenase (IDO) and IL-10 (Popov et al., 2006, 2008; Von Bergwelt-Baildon et al., 2006). Furthermore, it was shown that DCs with intermediate features between the immature and mature state expressing costimulatory molecules but only low levels of inflammatory cytokines, such as IL-12, IL-6, and TNF $\alpha$, are also characterized by regulatory function (Lutz and Schuler, 2002). Moreover, the potential therapeutical application of semi-mature DCs as tolerance promoters have been recently reviewed (Lutz, 2012).

In summary, there seems to be significant heterogeneity of DC populations with regulatory function, which might be due to the plasticity of DCs capable of reacting to and integrating environmental signals from different microenvironments. Nevertheless they share the ability (1) to regulate or inhibit $\mathrm{T}$ cell activation, and (2) to induce and promote $\mathrm{T}_{\text {reg }}$ development and expansion (Figure 1).

\section{ANTI-INFLAMMATORY MEDIATORS CAN DRIVE DCs TOWARD REGULATORY FUNCTION}

Since regulatory function of DCs is linked to environmental cues several soluble factors such as TGF $\beta$, IL-10, or $\mathrm{PGE}_{2}$ known to play a role in immune inhibition have been linked to the 
induction of regulatory DCs (Popov and Schultze, 2008). Even under steady state conditions, these factors play an important role for the integrity of many organ systems, particularly those with close contact to the outside world such as lung or intestine. For example the intestine is in constant contact with a large variety of antigens and it is of vital importance to discriminate between harmless nutrients, commensal flora, and potential threats (Iweala and Nagler, 2006). TGF $\beta$ is produced by intestinal epithelial cells thereby fostering the generation of $\mathrm{DC}_{\text {reg }}$ and subsequently $\mathrm{T}_{\text {reg }}$ cells. Neutralization of TGF $\beta$ directly leads to a diminished $\mathrm{DC}_{\text {reg }}$ capacity to induce $\mathrm{T}_{\text {reg }}$ cells (Iliev et al., 2009). Along the same lines, Belladonna and coworkers demonstrated that $\mathrm{CD}^{+}$pDC rely on autocrine TGF $\beta$ stimulation but also IDO to keep tolerance under steady state conditions. Moreover, they showed that $\mathrm{CD}^{-}{ }^{-}$immunogenic DCs do not produce TGF $\beta$ and yet externally added TGF $\beta$ induces IDO changing immunogenic DC into $\mathrm{DC}_{\text {reg }}$ (Belladonna et al., 2008). TGF $\beta$ also plays an important role for immunosuppression in the brain, which at least in part is also due to regulatory functions of DCs in this compartment. In a recent report, it could be demonstrated that blockade of TGF $\beta$ receptor signaling in DCs caused severe autoimmune encephalitis indicating an important role of this factor in DCs to maintain tolerance (Laouar et al., 2008). Another well-established factor inducing immunoregulatory functions in DCs is interleukin-10 (IL-10). DCs exposed to IL-10 fail to induce immunostimulatory cytokines such as IL-12 (De Smedt et al., 1997) or TNFa. Moreover, IL-10 prevents the upregulation of immunostimulatory molecules such as MHC class II and CD86. The quintessence is an impaired ability of IL-10 primed DCs to induce allogeneic T cell responses (Jonuleit et al., 2000; Moore et al., 2001; Pletinckx et al., 2011). Since the functional outcome of DCs depends on the exogenous signals integrated by these cells, it is not surprising that some factors can have both immunostimulatory as well as regulatory functions, depending on signal strength, time of exposure, and combination with other factors. The effect of $\mathrm{PGE}_{2}$ exemplifies such complex interaction. During acute inflammatory immune responses $\mathrm{PGE}_{2}$ is widely expressed by epithelial cells, fibroblasts, and immune cells infiltrating the inflamed site (Kalinski, 2012). In such situations $\mathrm{PGE}_{2}$ can serve as an enhancer of the immunostimulatory response. $\mathrm{PGE}_{2}$ also increases CCR7 expression and is essential to promote DC migration toward the lymph node-derived chemokines CCL19 and CCL21 (Scandella et al., 2002; Legler et al., 2006). However, more recently it has been reported that the $\mathrm{PGE}_{2}$ effect on CCR7 expression is only transient and that these $\mathrm{PGE}_{2}$-treated DCs secret reduced levels of CCL19, the key chemokine attracting naïve and central memory T cells (Muthuswamy et al., 2010). During extended inflammatory responses and in chronic inflammation, $\mathrm{PGE}_{2}$ might deviate DCs from a stimulatory into a regulatory phenotype. Under such conditions, $\mathrm{PGE}_{2}$ can induce regulatory mediators such as IL-10 (Kalinski et al., 1997) or thrombospondin-1 (Doyen et al., 2003). We have previously shown that TNFo signaling in presence of $\mathrm{PGE}_{2}$ induces regulatory DCs expressing a myriad of inhibitory molecules such as IDO, IL-10, soluble CD25 or COX-2 further increasing $\mathrm{PGE}_{2}$ production (Von BergweltBaildon et al., 2006; Driesen et al., 2008; Popov et al., 2008).
Finally exposure of DCs to $\mathrm{PGE}_{2}$ leads to increased IL-12p40 secretion which is not accompanied by production of IL-12p35 leading to an overall diminished production of the bioactive IL12 heterodimer (Kalinski et al., 2001; Von Bergwelt-Baildon et al., 2006).

As exemplified for TGF $\beta$, IL10 or $\mathrm{PGE}_{2}$, DCs can integrate signals from their microenvironment in a fashion that induces regulatory rather than immunostimulatory activity by these cells. Under steady state conditions such signal integration is critical for organ homeostasis. Any changes in the balance between regulatory and immunostimulatory signals can lead to tissue pathology. While decreased regulatory capacity of DCs can be associated with enhanced inflammatory responses associated with tissue destruction, increases in $\mathrm{DC}_{\text {reg }}$ are linked to chronic inflammation and malignant diseases.

\section{REGULATORY DCS IN CANCER}

Although there is clear evidence that the immune system can eliminate malignant cells the generation of a clinically efficient immune response against cancer is a challenging task (Schreiber et al., 2011). Over the last 15 years, therapies based on the immunostimulatory capacities of DCs have been a major focus of tumor immunotherapy, yet, most clinical studies have not resulted in meaningful clinical responses (Palucka and Banchereau, 2012). A major hurdle for DC-based tumor immunotherapy is to overcome regulatory circuits within the tumor microenvironment. In addition to many other cell types with regulatory or suppressive function such as myeloid derived suppressor cells (Palucka and Banchereau, 2012), $\mathrm{T}_{\text {reg }}$ cells or deviated macrophages, DCs also seem to be altered in various ways in malignancies (Table 1). In some cancer types DCs are depleted from the tumor site itself but also from the circulation suggesting that these malignancies induce significant changes in DC generation (Almand et al., 2000; Gabrilovich, 2004; Satthaporn et al., 2004; Tjomsland et al., 2010). In other cancer types, DC maturation was shown to be impaired and this feature was associated with lack of $\mathrm{T}$ cell activation and the induction of $\mathrm{T}$ cell anergy thereby inducing tolerance against the tumor (Ma et al., 2012; Shurin et al., 2012). In such situations, DC maturation might not simply be blocked, but more likely DCs are deviated toward a regulatory function by integrating signals from the tumor microenvironment (Gabrilovich et al., 2012). Such tumor-associated $\mathrm{DC}_{\text {reg }}$ are not only able to suppress effector $\mathrm{T}$ cells but also induce the recruitment and expansion of $\mathrm{T}_{\text {reg }}$ cells.

\section{FUNCTIONAL IMPAIRMENT OF DCS LEADS TO DEFECTIVE T CELL PROLIFERATION AND TOLERANCE}

At the same time when numerous clinical trials were already conducted to test the efficacy of DCs as cellular cancer vaccines it was revealed in human tumor biopsies as well as murine and rat tumor models that DCs in many malignancies present an impaired function, manifested in poor antigen processing and presentation, impaired migration and low presence of costimulatory molecules (Gabrilovich, 2004; Yang and Carbone, 2004). Early studies revealed that tumor infiltrating DCs present poor capabilities to induce $\mathrm{T}$ cell proliferation in an allogeneic mixed lymphocyte reaction in vitro (Troy et al., 1998). Consistent with 
Table 1 | Regulatory dendritic cells in immune diseases.

\begin{tabular}{|c|c|c|c|c|c|}
\hline Disease & DC phenotype & Surface marker & $\begin{array}{l}\text { Secreted immune } \\
\text { modulators }\end{array}$ & Literature & Function \\
\hline \multirow[t]{2}{*}{ Cancer } & $\begin{array}{l}\text { Impaired } \\
\text { maturation/immature }\end{array}$ & $\begin{array}{l}\text { Downregulation of } \\
\text { MHCII, CD80, CD83, } \\
\text { CD86 }\end{array}$ & Missing IL-12 & $\begin{array}{l}\text { Aalamian et al., 2001; } \\
\text { Gabrilovich, 2004; Yang } \\
\text { and Carbone, 2004; } \\
\text { Bharadwaj et al., 2007; } \\
\text { Michielsen et al., 2011; } \\
\text { Ma et al., 2012; Shurin } \\
\text { et al., } 2012\end{array}$ & $\begin{array}{l}\text { Induction of: T cell } \\
\text { anergy; } \\
\text { T cell apoptosis }\end{array}$ \\
\hline & Regulatory & CD25, PD-1, B7-H1 & $\begin{array}{l}\text { IL-10, TGF } \beta \text {, Kynurerine, } \\
\text { sCD25 } \\
\text { IDO, COX-2, ARG1 }\end{array}$ & $\begin{array}{l}\text { Toossi et al., 1990; } \\
\text { Williams et al., 1999; } \\
\text { Benoit et al., 2004; } \\
\text { Rodriguez et al., 2004; } \\
\text { Ghiringhelli et al., 2005; } \\
\text { Chemnitz et al., 2006; } \\
\text { Von Bergwelt-Baildon } \\
\text { et al., 2006; Chung et al., } \\
\text { 2009; Dumitriu et al., } \\
\text { 2009; Krempski et al., } \\
\text { 2011; Gabrilovich et al., } \\
\text { 2012; Scarlett et al., } 2012\end{array}$ & \\
\hline \multicolumn{6}{|c|}{ CHRONIC INFLAMMATION } \\
\hline $\begin{array}{l}\text { Systemic lupus } \\
\text { erythematosus }\end{array}$ & $\mathrm{pDCs}$ & $\begin{array}{l}\text { HLA-DR, CD4 (CD11c } \\
\text { reduced) }\end{array}$ & IFN $\alpha$, IL-10 & $\begin{array}{l}\text { Blanco et al., 2001; Lee } \\
\text { et al., 2008; Yan et al., } \\
\text { 2008; Jin et al., } 2010\end{array}$ & $\begin{array}{l}\text { Suppression of: } \\
\text { T cell activation; } \\
\text { T cell proliferation; } \\
\text { T cell function }\end{array}$ \\
\hline Rheumatoide arthritis & Regulatory & CD11b, CD11c, CD18 & TGF $\beta$, BAFF, IDO & $\begin{array}{l}\text { Morelli et al., 2003; } \\
\text { Zhang et al., 2005; } \\
\text { Kavousanaki et al., } 2010\end{array}$ & \\
\hline Parasitical infection & Regulatory & $\mathrm{CD} 11 \mathrm{c}, \mathrm{CD} 25$ & $\begin{array}{l}\text { TNF } \alpha \text {, IFN } \gamma, \text { IL-10, TGF } \beta \\
\text { COX2, IDO, S100 }\end{array}$ & $\begin{array}{l}\text { Von Bergwelt-Baildon } \\
\text { et al., 2006; Poncini } \\
\text { et al., 2008; Popov et al., } \\
\text { 2008; Li et al., } 2011\end{array}$ & \\
\hline
\end{tabular}

these findings DCs differentiated from monocytes in presence of conditioned media derived from prostate or pancreatic cancer cell lines, showed low levels of HLA-DR, costimulatory molecules CD40, CD80, CD86, and the DC maturation marker CD83 (Aalamian et al., 2001; Bharadwaj et al., 2007). Moreover, DCs cultured in presence of human colorectal cancer explants failed to upregulate CD86 and CD80 expression in response to LPS (Michielsen et al., 2011). Other examples for immune deviation of DCs in cancer came from rat cancer models demonstrating the presence of DCs expressing low levels of costimulatory molecules that were incapable of inducing $\mathrm{T}$ cell activation (Chaux et al., 1997; Bonnotte et al., 2004). These and many other reports suggested that the lack of immunostimulatory function of DCs in context of malignant disease was mainly due to lack of the necessary stimulatory molecules (MHC, CD80, and CD86) which might be explained by a strong influence of this field of research by findings in $\mathrm{T}$ cell immunology at the same time suggesting that presence or absence of costimulation on APC is mainly 
responsible for decision making between $\mathrm{T}$ cell immunity or tolerance. However, with the identification of regulatory cells such as $\mathrm{T}_{\text {reg }}$ cells and the appreciation of the complexity of immunoinhibitory signals within the tumor microenvironment, this rather simple model of lack of immune function by DCs has been gradually dismissed. In fact, it is now well appreciated that DCs in cancer can acquire a spectrum of different functional states ranging from strongly immunostimulatory to regulatory or even suppressive and inhibitory states inducing $\mathrm{T}$ cell tolerance or even deletion. Some of the molecular mechanisms responsible for regulatory rather than immunostimulatory functions of DCs in tumor microenvironments are described in the next section.

\section{DCs EXPOSED TO THE TUMOR MICROENVIRONMENT ACQUIRE A REGULATORY FUNCTION}

The tumor microenvironment provides many inhibitory signals that can be sensed by DCs leading to a change in their functional state. Soluble factors, such as IL-10, TGF $\beta$, and PGE (Popov and Schultze, 2008) secreted by the tumor have been clearly linked to the induction of $\mathrm{DC}_{\text {reg }}$ (Table 1). Furthermore, Scarllet and coworkers showed in a murine model of ovarian cancer that the switch from immunostimulatory to immunoregulatory function of mDCs at the tumor site determined the onset of aggressive malignant tumors that escaped immune surveillance (Scarlett et al., 2012). This data suggested that the interaction of DCs within the tumor microenvironment might be relevant in the control of disease progression-at least in ovarian cancer.

Among other factors, the enzymes IDO and arginase- 1 as well as TGF $\beta$ have clearly been linked to the generation and enrichment of $\mathrm{DC}_{\text {reg }}$ in the tumor microenvironment. IDO catalyzes the first rate-limiting step in tryptophan (Trp) degradation (Yamamoto and Hayaishi, 1967). Its activity has a dual effect leading to Trp depletion and accumulation of Trp catabolites, collectively known as kynurenines (Sugimoto et al., 2006). IDO expression has been detected in biopsies of patients with different malignancies such as esophageal (Von Bergwelt-Baildon et al., 2006), squamous cell carcinoma (McGee-Lawrence et al., 2011), non-small cell lung carcinoma (Sim et al., 2012), and melanoma amongst others (Munn and Mellor, 2007). IDO activity was linked to multiple mechanisms in immune tolerance in vitro as well as in vivo. Trp starvation and accumulation of Trp catabolites lead to $\mathrm{T}$ cell proliferation arrest and apoptosis (Terness et al., 2002; Von Bergwelt-Baildon et al., 2006). Furthermore, DCs can induce the expansion of autologous $\mathrm{T}_{\text {reg }}$ via an IDOdependent mechanism (Chung et al., 2009). More recently, it has been reported in mice that the Trp catabolite kynurenine can bind and activate the aryl hydrocarbon receptor (AHR) on T cells leading to AHR-dependent $\mathrm{T}_{\text {reg }}$ generation (Mezrich et al., 2010). The induction of active allograft-specific tolerance by AHR activation has been described earlier in Balb/c mice (Hauben et al., 2008). In this study DC out of VAG539-tolerized mice induced the development of $\mathrm{CD} 25^{+}$Foxp $3^{+} \mathrm{T}$ cells.

Our group has shown that $\mathrm{mDC}$ cultured in the presence of TNF $\alpha$ and $\mathrm{PGE}_{2}$, two factors with high abundance in the microenvironment of many tumors (Williams et al., 1999; Benoit et al., 2004; Chemnitz et al., 2006), upregulated IDO expression concomitant with an increased expression of IL-10, COX-2, and the interleukin 2 receptor alpha chain (CD25) (Popov et al., 2006, 2008; Von Bergwelt-Baildon et al., 2006; Driesen et al., 2008). Soluble CD25 has been associated with poor prognosis in solid and hematological malignancies (Paietta et al., 1997) All these immunoregulatory mechanisms together equip $\mathrm{DC}_{\text {reg }}$ with powerful mechanisms to restrain $\mathrm{T}$ cell responses. $\mathrm{IDO}^{+} \mathrm{DC}_{\mathrm{reg}}$ can mediate apoptosis of effector $\mathrm{T}$ cells and at the same time promote $\mathrm{T}_{\text {reg }}$ cell expansion thereby shifting the balance further toward immune inhibition or suppression (Fallarino et al., 2002). Furthermore, we demonstrated that cell surface expression of CD25 and secretion of soluble CD25 act as decoy receptors for IL-2 (Toossi et al., 1990; Von Bergwelt-Baildon et al., 2006) which further inhibits $\mathrm{T}$ cell function. Since, $\mathrm{IDO}^{+} \mathrm{CD} 25^{+} \mathrm{DC}_{\mathrm{reg}}$ are present in the tumor microenvironment one could postulate that these regulatory cells_-similar to other myeloid cells with inhibitory functions are part of the immune deviation from activation to inhibition in the tumor microenvironment. In this context, a rather alerting observation was made during a clinical vaccine trial. Patients treated with $\mathrm{MDC}$ based cancer vaccines showed a recruitment of $\mathrm{IDO}^{+}$immune cells together with $\mathrm{T}_{\text {reg }}$ cells to the site of injection suggesting that under some circumstances such cellular therapies might actually enhance regulatory functions of DCs rather than potentiating immune activation (Wobser et al., 2007).

In addition to $\mathrm{IDO}^{+}$mDCs, the accumulation of $\mathrm{pDCs}$ in tumors and tumor lymph nodes is also well documented for different malignancies including melanoma (Vermi et al., 2003) or head and neck cancer (Hartmann et al., 2003). Moreover, $\mathrm{IDO}^{+}$pDCs present in murine and human tumor-draining lymph nodes, were reported to induce $\mathrm{T}$ cell anergy toward specific tumor antigens. Importantly, the interaction of CD80/CD86 receptors on $\mathrm{IDO}^{+}$pDCs with CTLA- 4 on $\mathrm{T}_{\text {reg }}$ cells was an important molecular interaction leading to $\mathrm{T}_{\text {reg }}$ cell expansion and subsequently antigen-specific anergy in effector $\mathrm{T}$ cells (Baban et al., 2005). More recently, Watkins and coworkers reported the presence of $\mathrm{IDO}^{+} \mathrm{pDCs}$ in human and murine prostate cancer. These $\mathrm{IDO}^{+}$DCs suppressed $\mathrm{T}$ cell proliferation and induced $\mathrm{T}$ cell tolerance. By gene expression profiling the authors defined a regulatory gene signature of these $\mathrm{IDO}^{+} \mathrm{pDCs}$, which was controlled by the transcription factor FOXO3 (Watkins et al., 2011).

Another enzyme that has been implicated as an immunoregulatory molecule in myeloid cells including DCs in the tumor context is arginase-1 (ARG1). ARG1 catalyzes arginine conversion into urea and L-ornithine, causing the depletion of the non-essential amino acid arginine (Munder, 2009). High ARG1 activity has been described in patients with various malignancies including gastric, colon, breast, and lung cancers (Rodriguez et al., 2004). In murine models it was reported that mDC upregulate ARG1 when exposed to different cancer cell lines. Moreover, $\mathrm{ARG}^{+}$mDC suppressed $\mathrm{T}$ cell proliferation via arginine depletion (Liu et al., 2009; Norian et al., 2009). In T cells L-arginine deprivation leads to an arrest of the cell cycle during G0-G1 transition (Rodriguez et al., 2007) and to reduced expression of the TCR $\zeta$-chain (Rodriguez et al., 2004). These findings suggest that upregulation of ARG1 is yet another mechanism of $\mathrm{DC}_{\text {reg }}$ that 
impacts on the outcome of T cell activation, at least in the murine model. However, the relevance of these findings in human tumors has not yet been clarified.

A major immunosuppressive factor within the tumor microenvironment is TGF $\beta$ ( $\mathrm{Li}$ and Flavell, 2008). It has been well documented that mDCs upregulate TGF $\beta$ expression and secrete TGF $\beta$ once exposed to tumor cell lines, e.g., non-small cell lung carcinoma cell lines (Dumitriu et al., 2009). Moreover, interaction of $\mathrm{T}$ cells with TGF $\beta$ producing $\mathrm{mDC}$ leads to the induction of $\mathrm{CD} 4^{+} \mathrm{CD} 25^{+}$Foxp $3^{\text {high }} \mathrm{T}$ cells (Dumitriu et al., 2009). Consistent with these findings Ghiringhelli and coworkers showed in mouse and rat colon cancer models that DCs exposed to tumor cells could acquire the capacity to secrete TGF $\beta$ and to stimulate naturally occurring $\mathrm{T}_{\text {reg }}$ cells in vivo (Ghiringhelli et al., 2005). Therefore, expression of TGF $\beta$ is yet another mechanisms by which DCs exert regulatory rather than immunostimulatory function in the tumor microenvironment. More recently, the expression of inhibitory cell surface molecules PD-1 and B7-H1 on a subset of DCs in a murine model of ovarian cancer was linked to suppression of $\mathrm{T}$ cell proliferation and this effect could be abolished by blocking antiPD-1 antibodies (Krempski et al., 2011). These data suggest that PD-1 and B7-H1 expression on DC can also contribute to immunoregulation or suppression by DCs in the tumor microenvironment. Altogether, there is accumulating evidence that the absence of $\mathrm{T}$ cell immunity in cancer is not solely due to the lack of expression of MHC and costimulatory molecules on DCs. Rather the existence of multiple inhibitory pathways and effector molecules in tumor-associated DCs are major mechanisms of immune deviation in cancer and DCs showing such hallmarks are part of a larger family of regulatory DCs. Further studies are necessary to delineate whether a hierarchy of regulatory pathways exists or whether these mechanisms are co-existing. This will be particularly important when developing novel strategies to overcome immunoregulation in the tumor microenvironment as a basis for the development of effective cancer immunotherapy.

\section{DENDRITIC CELLS IN CHRONIC INFLAMMATION}

Chronic inflammation results from prolonged inflammatory immune responses that are not terminated despite the fact that the causing stimuli are often eliminated. Stimuli inducing chronic inflammatory responses vary widely ranging from numerous pathogens, self-antigens to chemical compounds. Chronic inflammatory responses are associated with diseases such as diabetes, atherosclerosis, or obesity. Another deviation from a normal immune response occurs in many autoimmune diseases and chronic exposure to allergens. Allergic responses can turn into prolonged inflammatory responses with significant changes of the inflammatory response during later time points which is similarly observed in many autoimmune diseases. In such situations, resident immune cells become continuously activated and recruit further immune cells which invade the inflamed tissue further fueling the inflammatory response. Albeit pro-inflammatory cytokines, NO, arachidonic acid metabolites and ROS are major compounds under such conditions, mechanisms exist that change the cellular programs of immune cells from immunostimulatory programs resolving inflammation to chronic inflammatory programs supporting chronification of the response. Again, myeloid cells including both macrophages and DCs play an essential role in deregulating inflammatory responses into chronic inflammation.

\section{REGULATORY MECHANISMS IN DCS SEEM TO BE DEFECTIVE IN SYSTEMIC LUPUS ERYTHEMATOSUS}

While regulatory or suppressive myeloid cells seem to play a central role for immune deviation in cancer, regulatory functions of these cells seem to be reduced or even lacking in autoimmune diseases such as systemic lupus erythematodes (SLE), rheumatoid arthritis, or psoriasis (Table 1). SLE is an autoimmune disease characterized by the loss of tolerance against self-antigens. Furthermore, an imbalance of $\mathrm{T}_{\mathrm{H}} 1$ and $\mathrm{T}_{\mathrm{H}} 2$ cells in favor of $\mathrm{T}_{\mathrm{H}} 2$ responses has been reported to be accommodated by decreased expression of IL-18 with unchanged expression levels of IL-10 in pDCs of SLE patients (Jin et al., 2010). Despite this dysbalance in pDCs that might favor immunoregulation when using pDCs of SLE patients in allogeneic MLR assays they failed to induce the expansion of Foxp3 expressing CD4 ${ }^{+} \mathrm{CD} 25^{+} \mathrm{T}_{\text {reg }}$ cells (Jin et al., 2010). These data follow along the lines that activated DCs in this autoimmune disease might be incapable of suppressing effector $\mathrm{T}$ cell activation thereby contributing to the persistence of inflammation. Despite the lack of DCs to induce $\mathrm{T}_{\text {reg }}$ cells, Foxp $3^{+} \mathrm{CD} 4{ }^{+} \mathrm{CD} 25^{+} \mathrm{T}$ cells have been reported to be elevated in peripheral blood of SLE patients, however their suppressive function seemed to be impaired which was related to high levels of IFN $\alpha$ secreted by antigen presenting cells (APCs) of SLE patients (Yan et al., 2008). In SLE patients $\mathrm{pDCs}$ seem to be a main source for IFN $\alpha$. It is assumed that immune complexes containing DNA or RNA act as inflammatory stimuli maintaining the IFN $\alpha$ production in $\mathrm{pDCs}$ via TLR7 and TLR9 (Means et al., 2005; Savarese et al., 2006). However, other immune cells might also contribute to the interferon storm. For example, monocytes cultured in the presence of IFN $\alpha$-rich sera from SLE patients differentiated into IFN $\alpha$ producing DCs (Blanco et al., 2001; Ueno et al., 2007) suggesting that a feed-forward loop exists that supports chronification of the autoimmune response in SLE. In a murine model of SLE chronification of the immune response inducing IFN $\alpha$ production in immature Ly6 $\mathrm{C}^{\text {high }}$ monocytes can also be initiated by treatment with tetramehtylpentadecane (Lee et al., 2008) further supporting the hypothesis that the lack of induction of DCs with regulatory function is a major mechanisms of prolongation of exacerbated autoimmune responses in SLE patients. As a logical consequence novel therapeutic concepts for SLE are targeting at the point of induction of regulatory DCs. For example, Zhang and coworkers recently described that treatment with immune complexes lead to elevated levels of $\mathrm{PGE}_{2}$ secretion by Fc $\gamma$ RIIboverexpressing DCs which correlated with an elevated capacity to suppress T cell activation (Zhang et al., 2011). Clinically, injection of immune complex-treated Fc $\gamma$ RIIb-overexpressing DCs into lupus-prone MRL/lpr mice was associated with prolonged survival of these mice. In another mouse model the nucleosomal histone peptide epitope H4(71-94) was used in subnanomolar doses to induce $\mathrm{DC}_{\text {reg }}$ which expressed TGF $\beta$ but showed 
reduced levels of IL-6 supporting the generation of $\mathrm{T}_{\text {reg }}$ cells and suppression of pro-inflammatory $\mathrm{T}_{\mathrm{H}} 17$ cells (Kang et al., 2007). One other therapeutical approach targeted the central pro-inflammatory transcription factor $\mathrm{NF \kappa B}$. Inhibition of this transcription factor in a murine SLE model in Fc $\gamma$ RIIb-deficient mice with andrographolide or the anti-diabetic drug rosiglitazone lead to induction of $\mathrm{DC}_{\text {reg }}$ (Kalergis et al., 2009). The diureticum triamterene is another compound which might be useful for the therapy of SLE because it is able to induce IDO activity in mDCs and such $\mathrm{IDO}^{+}$DCs have been described to induce fully functional Foxp 3 positive CD ${ }^{+} \mathrm{CD} 25^{+} \mathrm{T}$ cells (Ghosh and Branch, 1975; Chung et al., 2009).

\section{LACK OF REGULATORY DC FUNCTION IS ASSOCIATED WITH JOINT INFLAMMATION IN RHEUMATOID ARTHRITIS AND PSORIASIS}

As revealed in murine model systems, DCs play an essential role in keeping immune homeostasis in the joint. Under these conditions, joint derived self-antigens from apoptotic cells can be recognized by DCs via the heterodimeric receptors CR3 (CD11c/CD18) and CR4 (CD11b/CD18) belonging to the $\beta 2$ integrin family of adhesion molecules (Morelli et al., 2003). Activation of DCs by these receptors induces a regulatory DC phenotype associated with suppressed IL-12 production and elevated secretion of TGF $\beta$. Moreover, it was shown that such DCs are capable of inducing $\mathrm{T}$ cell anergy (Morelli et al., 2003).

Rheumatoid arthritis (RA) is a chronic autoimmune disease associated with production of elevated levels of pro-inflammatory cytokines, including IL-12, IL-6, IL-1, IL-23, and TNF $\alpha$, that are involved in activation of naïve $\mathrm{T}$ cells and directing their polarization into $\mathrm{T}_{\mathrm{H}} 1$ and $\mathrm{T}_{\mathrm{H}} 17$ cells. DCs are implicated as major players for the development and persistence of inflammation but also the resulting joint and bone destruction (Table 1). Albeit the number of $\mathrm{CD}_{303}{ }^{+} \mathrm{pDC}$ and $\mathrm{CD} 1 \mathrm{c}^{+}$mDCs is significantly reduced (Kavousanaki et al., 2010) in patients with active RA, DCs invading synovial fluids are quickly activated in response to joint-associated factors such as cartilage glycoprotein 39 but also pro-inflammatory stimuli including cytokines and chemokines and other proteins derived from dying cells within synovial fluids (Van Bilsen et al., 2004). DCs in RA patients are also involved in elevated B cell activation followed by proliferation and antibody production. As shown in a murine collagen-induced arthritis model $\mathrm{B}$ cell activation seems to be mainly related to the secretion of the cytokine BAFF (B-cell activating factor) which belongs to the TNF family (Zhang et al., 2005). A switch from regulatory to inflammatory functions of DCs together with an overall reduced number of $\mathrm{DC}_{\text {reg }}$ in $\mathrm{RA}$ patients suggests that a reprograming of DCs back to a regulatory phenotype might be an appealing therapeutic strategy for these patients. In fact, higher numbers of pDCs expressing IDO were found in peripheral blood of RA patients following current therapy regimens. These $\mathrm{DC}_{\text {reg }}$ were reported to convert naïve $\mathrm{T}$ cells into IL-10 secreting $\mathrm{T}_{\text {reg }}$ cells (Kavousanaki et al., 2010). Therefore, a more specific therapeutic attempt in comparison to currently used global immune suppressive drugs, like methotrexate and infliximab, might be to revert back highly activated DCs showing a pro-inflammatory profile into $\mathrm{DC}_{\text {reg }}$ capable of suppressing autoreactive $\mathrm{T}$ cells.
Indeed, several early ex vivo vaccination trials, like for example the phase I clinical trial Rheumavax at the University of Queensland (Australia) or AutoDECRA at Newcastle University (UK) aim to reestablish $\mathrm{T}$ cell tolerance by induction of $\mathrm{T}_{\text {reg }}$ cells via modification of DC function. Another approach might be to disrupt costimulatory interactions between DCs and T cells. Cytotoxic T lymphocyte antigen-4 (CTLA4) fused to IgG1 interrupts the costimulatory B7/CD28 interaction between T cells and DCs preventing the activation and proliferation of $\mathrm{T}$ effector cells (Dall'Era and Davis, 2004). Furthermore, the binding of CTLA4 or its IgG1 fusion molecule was found to induce IDO expression in DC after binding to the B7 surface receptor (Grohmann et al., 2002). Adoptive transfer of CTLA4-Ig treated CD11c ${ }^{+}$ DCs into collagen-induced arthritic mice induced the expansion of $\mathrm{CD}^{+}{ }^{+} \mathrm{CD} 25^{+}$Foxp3 $^{+} \mathrm{T}_{\text {reg }}$ cells and prevented the onset of arthritis efficiently (Ko et al., 2010). Another approach to target costimulation was recently achieved by siRNA (short interfering RNAs) technology. DCs loaded with the arthritogenic Ag collagen II and treated with siRNAs targeting the costimulatory molecules CD40, CD80, and CD86 were used in an arthritis mouse model. Treatment with these re-programmed DCs resulted in downregulation of IL-2, IFN $\gamma$, TNF $\alpha$, and IL-17, which in turn resulted in elevated levels of Foxp $3^{+} \mathrm{T}_{\text {reg }}$ cells (Zheng et al., 2010). Another approach to induce $\mathrm{DC}_{\text {reg }}$ was recently published demonstrating that dual lentiviral transfer of a constitutive MEK-1 mutant with a fusion protein containing invariant chain of $\mathrm{MHC}$ and ovalbumin (IiOVA) leads to activation of ERK signaling thereby inducing TGF $\beta$ production by DCs (Arce et al., 2011). As a consequence ERK-activated DCs induced the expansion of Foxp $3^{+} \mathrm{T}_{\text {reg }}$ cells which prevented joint destruction.

Another example for the lack of DC regulatory function in autoimmunity is psoriasis, one of the most common inflammatory diseases, which is characterized by dermatosis with hyperproliferation of keratinocytes. In this autoimmune disease autoreactive, constitutively activated $\mathrm{T}$ cells secrete cytokines which support the proliferation of dermal cells. Genetic, environmental and immunological factors define the severity of psoriasis, but the cause of the disease is still unknown. Psoriasis is also characterized by a reduced number of circulating pDCs while at the same time increased numbers of pDCs are recruited to psoriatic lesions and healthy skin (Skrzeczynska-Moncznik et al., 2009). IFN $\alpha$ itself, but also other soluble mediators like chemerin have been suggested to be responsible for this relocation of pDCs in psoriasis (Skrzeczynska-Moncznik et al., 2009). In the early phase of psoriasis pDCs themselves secrete IFN $\alpha$ subsequently inducing the activation and expansion of $\mathrm{T}$ cells (Nestle et al., 2005). Elevated expression of IFN $\alpha$ by DCs in psoriasis might be related to the identification of high level expression of the endogenous anti-microbial peptide LL37 in psoriatic lesions. LL37 can bind to self-DNA resulting in complex structures that activate $\mathrm{pDCs}$ via the pattern recognition receptor TLR9 thereby inducing IFN $\alpha$ secretion (Lande et al., 2007). If IFN $\alpha$ is essential for the pathogenesis of psoriasis, its blockade should reduce psoriatic symptoms. Indeed, using blocking anti-IFN $\alpha$ antibodies prevented the development of psoriasis in a xenograft model in mice (Nestle et al., 2005). In addition to IFN $\alpha$ blockade other attempts to reestablish $\mathrm{DC}_{\text {reg }}$ in psoriasis 
have been suggested. An interesting strategy to induce $\mathrm{DC}_{\text {reg }}$ was recently reported by stimulating DCs with the neuropeptide $\alpha$-melanocyte-stimulating hormone ( $\alpha$-MSH). $\alpha$-MSH stimulated DCs downregulated the costimulatory molecules CD80 and CD86, upregulated the two coinhibitory molecules PD-L1 and PD-L2, as well as CD205 and secreted high amounts of IL-10. These DCreg subsequently induced CD $4{ }^{+} \mathrm{CD} 25^{+}$Foxp $3^{+}$ $\mathrm{T}_{\text {reg. }}$. Mutation experiments of the MC-1R gene showed that the induction of $\mathrm{DC}_{\text {reg }}$ was mediated by the binding of $\alpha-\mathrm{MSH}$ to the $\mathrm{MC}-1 \mathrm{R}$ and that this effect could ameliorate psoriasis in vitro as well as in vivo (Auriemma et al., 2012). Another approach to induce $\mathrm{DC}_{\text {reg }}$ was based on vitamin $\mathrm{D}$. An activated form of vitamin $\mathrm{D}$, namely 1,25-dihydroxyvitamin D3 has been described to inhibit the differentiation and maturation of DCs by its influence on RNA Polymerase II-mediated transcription of response genes (Penna and Adorini, 2000). Downregulation of activation-associated molecules such as CD1a was associated with diminished IL-12 secretion, and upregulation of IL-10 reprogramed DCs toward regulatory functions thereby gaining the capacity to induce $\mathrm{T}_{\text {reg }}$ cells (Piemonti et al., 2000).

\section{MYELOID CELLS ARE INVOLVED IN CHRONIC INFLAMMATION IN OBESITY}

The observation that increased adipose tissue in obesity is associated with the influx of immune cells, mainly myeloid cells has been made less than 10 years ago (Wellen and Hotamisligil, 2003; Chawla et al., 2011). Obesity is associated with Type 2 Diabetes (T2D), insulin resistance, arteriosclerosis, other cardiovascular diseases and even increased cancer risk (Lumeng and Saltiel, 2011). Elevated levels of free fatty acids (FFAs) and proinflammatory cytokines are hallmarks of the systemic low-grade inflammation persisting in obese individuals (Roytblat et al., 2000; Hansen et al., 2010). In mouse models massive infiltration of immune cells into adipose tissue has been described suggesting to promote high-fat died induced adipose tissue inflammation (Duffaut et al., 2009; Strissel et al., 2010). While macrophages clearly play a major role during this chronic inflammation the role of DCs in the inflammatory cross-talk of adipocytes and immune cells is not yet clear (Table 1). The impact of dietary fatty acids on the presence of DCs in adipose tissue adjacent to and remote from lymph nodes has been investigated under conditions of chronic mild inflammation induced by low doses of LPS in rats (Mattacks et al., 2004). Chow containing fish oil which is rich in unsaturated fatty acids (USFAs) is considered to reduce inflammatory effects while diets enriched for oils containing saturated fatty acid (SFAs) were associated with an increase of DCs in perinodal adipose tissue (Mattacks et al., 2004). So far, little is known about the role of elevated levels of FFAs on DC function. However, one could speculate that-similar to macrophages-FFAs will shape the functional program of DCs. Using fluorescently labeled palmitic acid, it was recently demonstrated that DCs can uptake fatty acids (Herber et al., 2010). Interestingly, little is known about the accumulation and storage of FFAs in DCs and what role lipid droplets might play in DCs. Increased levels of fatty acids have an impact on antigen processing and presentation. Splenic DCs derived from mice with non-alcoholic fat liver disease (NAFLD), an obesity associated disease, were found to show an impaired processing and presentation of HBsAg in the presence of the saturated fatty acid palmitic acid, but not the unsaturated fatty acid oleic acid (Miyake et al., 2010). Similarly, human blood-derived DCs challenged with antigen demonstrated reduced antigen presentation in vitro, lower induction of $\mathrm{T}$ cell proliferation and also an induction of the two pro-inflammatory cytokines IL- $1 \beta$ and $\mathrm{TNF} \alpha$ in the presence of palmitic acid but not oleic acid (Miyake et al., 2010). Due to the complexity of FFAs concerning saturation, length and isomer structure, it is very likely that mixture of FFAs results in similarly complex immune responses due to differential signal integration. For most FFAs the impact on DC function is not yet understood. One possible receptor for fatty acids is the scavenger receptor CD36 on DCs and various other cells (Silverstein and Febbraio, 2009). But also PRR are involved in the detection of some FFAs. For example, the satured fatty acid lauric acid is recognized via TLR4, one of the major receptors for PPRs on DCs. Recognition of lauric acid via TLR4 was found to upregulate costimulatory molecules CD40, CD80, CD86, MHCII, and to enhance secretion of IL-12 subsequently triggering $\mathrm{T}$ cell activation (Weatherill et al., 2005). The opposite effect was shown for DCs stimulated with the omega3 unsaturated fatty acid docosahexaenoic acid. This fatty acid inhibited LPS-induced upregulation of CD40, CD80, and CD86 as well as MHC class II molecules and prevented T cell activation. Due to these immunoinhibitory effects of unsaturated fatty acids, they might be useful as therapeutics in chronic inflammatory diseases, including obesity, cardiovascular disease, Bowel disease, Crohn's disease, or chronic obstructive pulmonary disease (Blok et al., 1996; Caughey et al., 1996; Calder, 1997; De Batlle et al., 2011; Bassaganya-Riera et al., 2012; Huang et al., 2012). A cis-9, trans-11 isomer of conjugated linoleic acid is a poly-unsaturated fatty acid naturally occurring in meat, milk, and other nutrients. It has been shown to induce the expression of the anti-inflammatory cytokine IL-10 in murine bonemarrow derived DCs in an ERK dependent fashion (Loscher et al., 2005). As negative feedback loop IL-10 inhibited NFKB leading to suppression of its downstream target IL-12 which might contribute to its immunosuppressive properties on $\mathrm{T}_{\mathrm{H}} 1$ cell activation (Loscher et al., 2005). Besides TLR4 also peroxisome proliferation-activator receptor-gamma (PPAR $\gamma)$ can affect the maturation status of DCs (Chinetti et al., 2000; Nencioni et al., 2002). Upregulation of PPAR $\gamma$ was observed in docosahexaenoic acid or eicosapentaenoic acid stimulated bone marrow derived DCs. These cells showed reduced IL-12 secretion, reduced expression of costimulatory molecules, and reduced NFKB activity, but enhanced expression of IL-10R and its ligand IL-10 (Draper et al., 2011). Despite an increased physical interaction and cellular colocalization of NFKB and PPAR $\gamma$ the same study showed that the anti-inflammatory effect of the two tested omega-3 USFAs was not abolished by the inhibition of PPAR $\gamma$ with a chemical inhibitor compound. These results lead to the conclusion, that $\operatorname{PPAR} \gamma$ might be an intracellular receptor for unsaturated fatty acids but cannot be singularly made responsible for the inflammatory effects of polyunsaturated fatty acids. Finally, it should be mentioned that resolvins and lipoxins, metabolites of docosahexaenoic acid or eicosapentaenoic acid, have anti-inflammatory 
functions and are involved in downregulation of IL-12 secretion in DCs via downregulation of the chemokine receptor 5 (CCR5) (Aliberti et al., 2002).

Beneficial usage of omega- 3 unsaturated fatty acids has been shown in clinical trials to improve plasma triglyceride levels and insulin activity in T2D patients (Hendrich, 2010). T2D is often associated with obesity and characterized by elevated plasma concentrations of the pro-inflammatory cytokines TNF $\alpha$ and granulocyte-macrophage colony-stimulating factor driving chronic low grade inflammation systemically (Surendar et al., 2012). These two pro-inflammatory mediators contribute to the activation of circulating $\mathrm{CD} 5^{+} \mathrm{CD} 123^{+}$pDCs and $\mathrm{CD} 85^{+}$ $\mathrm{CD}^{+} 3^{+} \mathrm{CD} 123^{\mathrm{dim}} \mathrm{mDCs}$ yet the overall number of DCs is reduced in $\mathrm{T} 2 \mathrm{D}$ making diabetic patients prone to infections (Seifarth et al., 2008; Blank et al., 2010). Interestingly, DCs seem to be reprogrammed once concomitant health problems such as arteriosclerosis are acquired. In T2D patients with atherosclerotic complications circulating monocytes and DCs show reduced production of pro-inflammatory mediators like $\mathrm{TNF} \alpha$ which is associated with impaired T cell activation (Corrales et al., 2007). Taken together, DCs like macrophages are involved in chronic low-grade inflammation observed in obesity. Elevated levels of free fatty acids, a hallmark of obesity, have substantial influences on DCs with saturated fatty acids inducing pro-inflammatory immune mediators. On the other hand, unsaturated fatty acids seem to suppress inflammation and are currently investigated as an attractive therapeutic option in obesity. Therefore, unsaturated fatty acids constitute yet another mechanism capable of inducing regulatory programs in DCs.

\section{REGULATORY DCS ARE INDUCED DURING CHRONIC INFECTIONS}

In general, the immune system is equipped to resolve most acute infections by completely removing invading pathogens. However, some pathogens have evolved strategies to escape a resolving immune response and as a consequence induce chronification of the infection. Chronic infections are also characterized by a deviated immune response often resulting in a prevalence of immunoregulatory mechanisms including regulatory cells. In fact, increasing evidence exists suggesting that $\mathrm{DC}_{\text {reg }}$ also play a role in chronic infections. In some situations such as the development of chronic granulomatous infections, the development of regulatory mechanisms actually might be the last resort of the host to keep the invading pathogens in check. Using a few examples, we illustrate the evidence for $\mathrm{DC}_{\text {reg }}$ in chronic infections.

\section{DEVIATION OF DC FUNCTION DURING VIRAL INFECTIONS}

Under normal conditions, RNA and DNA viruses activate DCs e.g., via the PPRs TLR7 or TLR9 resulting in enhancement of IFN $\alpha$ production by matured DCs. In some viral infections lack of viral clearance is - at least in part-due to lack of an effective DC activation and maturation (Table 1). For example although hepatitis $\mathrm{C}$ virus (HCV) is recognized by DCs via binding of the $\mathrm{HCV}$ envelope 2 protein to surface receptors such as SRBI, DC-SIGN, CD81 or TLR receptors other viral proteins inhibit important steps of DC maturation, prevent IL-12 induction and subsequently reduce their capacity to induce $\mathrm{T}$ cell activation (Sarobe et al., 2003). During monocyte differentiation HCV inhibits the expression of CD1a, CD1b, and DC-SIGN, but induces these DCs to secret IL-10 preventing T cell expansion (Tu et al., 2012). Attempts to decipher the molecular mechanism of the immune suppressive pathways activated by HCV revealed that after exposure of pDCs to HCV-infected hepatoma cells they activated IRF7 but not the central pro-inflammatory transcription factor NFKB. These finding might explain, why pDCs in HCV infection secrete IFN $\alpha$ but are not able to produce IL- 6 or TNF $\alpha$ (Dental et al., 2012). In mice, the function of DCs was recovered when DCs were pulsed ex vivo with the viral protein NS3 and matured in the presence of CpG (Yu et al., 2006). Unlike HCV infection, the capability to secrete IL-12 is not impaired in herpes simplex virus type 1 (HSV1) infected DCs. In an initial report, DCs infected with HSV1 were reported to show many phenotypical features of matured DCs except for a loss of CD83 and reduced T cell stimulating activity (Kruse et al., 2000). A more recent study however demonstrated in a murine model that the HSV1 latencyassociated transcript (LAT) is involved in the downregulation of costimulatory molecules and pro-inflammatory cytokines like IL-6, IL-12, and TNF $\alpha$ (Chentoufi et al., 2012). Impaired DC function was also suggested to contribute to the reduced function of HSV-specific CD8 ${ }^{+}$T cells (Chentoufi et al., 2012). Moreover, LAT can function like endogenous cFLIP inhibiting caspase8 mediated apoptosis in HSV-infected DCs thereby ensuring spreading and replication of the virus (Kather et al., 2010). Yet other mechanisms of immune deviation operative in DCs have been suggested for human immunodeficiency virus (HIV) infection. In the early phase of primary HIV infection, numbers of $\mathrm{CD}_{11 \mathrm{c}^{+}}$mDCs as well as $\mathrm{CD} 123^{+}$pDC are decreased resulting in a lack of anti-viral IFN $\alpha$ expression (Pacanowski et al., 2001). Infected DCs display a rather immature phenotype because they do not really upregulate typical activation markers like $\mathrm{MHC}$ class II, CD83, CD80, CD86, or CCR7 (Smed-Sorensen et al., 2004; Martinson et al., 2007). Their functional potential is controversially discussed. Although the number of circulating DCs is declinedin HIV patients, the remaining DCs seem to keep a certain immune activating potential as exemplified by CD86 upregulation after stimulation with CD40L. Also these DC secrete TNF $\alpha$, IL-1 $\beta$, and IL-10 but do not secrete IL-12 p70 or IFN $\alpha$ (Smed-Sorensen et al., 2004; Martinson et al., 2007). The induction of IFN regulatory factor 1 (IRF-1) by HIV infection of DCs was shown to induce IFN-stimulated genes without the expression of type I and II interferons thereby ensuring the replication of the HIV in mDCs (Harman et al., 2011). In fact, the loss of IFN $\alpha$ production of HIV infected $\mathrm{pDC}$ was postulated to contribute to progression of the disease (Tilton et al., 2008). Furthermore, HIV infected DCs are resistant to NK cell mediated cell death. Melki and coworkers showed an upregulation of the anti-apoptotic molecules c-FLIP and c-IAP2 in these DCs rendering them resistant to TRAIL-induced cell death via interaction between TRAIL on the cell surface of NK cells and its receptor DR4 on DCs (Melki et al., 2010).

These are only few examples, demonstrating that the induction of DCs with regulatory rather than stimulatory functions is a major theme of many viruses capable of escaping an efficient immune response thereby inducing viral persistence. 


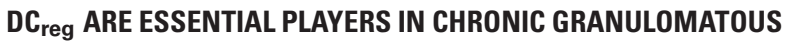 LISTERIOSIS}

Myeloid cells with regulatory function have also been implicated in the formation and maintenance of granulomatous structures that are supposed to enclose pathogens thereby preventing their dissemination (Table 1). While macrophages play the major role in most granulomatous diseases chronic granulomatous listeriosis is characterized by large quantities of DCs within the cellular ring wall of the granuloma (Popov et al., 2006). Listeriosis is caused by the gram positive bacteria Listeria monocytogenes (L.m.). In the immunocompetent host, clinical manifestation is characterized by a self-limiting gastroenteritis. However, in immunocompromised individuals, but also elderly people and newborns L.m. can cause chronical meningoencephalitis and septicemia (Swaminathan and Gerner-Smidt, 2007; Allerberger and Wagner, 2010; Mook et al., 2011). Moreover, advanced stages of chronic disease are characterized by granulomas in lymph node tissue (Gray and Killinger, 1966). Granulomas are organized immune cell aggregates that form in response to persistent stimuli of infectious or non-infectious nature (Ramakrishnan, 2012). Recently, our group discovered that $\mathrm{CD} 11 \mathrm{c}^{+} \mathrm{S} 100^{+} \mathrm{IDO}^{+} \mathrm{mDCs}$ are predominant constituent elements in the outer wall of listeria granuloma (Popov et al., 2006, 2008; Von Bergwelt-Baildon et al., 2006). Transcriptome profiling of L.m. infected mDCs revealed that infection of $\mathrm{mDCs}$ leads to the upregulation of numerous effector molecules including TNF $\alpha$, IFN $\gamma$, IL-10, COX-2, IDO, and CD25 that act together in a regulatory fashion (Popov et al., 2008). Supernatants derived from mDCs infected by L.m. suppressed $\mathrm{T}$ cell proliferation via a mechanism that involves IDO activity, (Popov et al., 2008 and Schultze, unpublished data). Furthermore, $\mathrm{IDO}^{+}$mDCs were also capable to keep L.m. in check, suggesting that IDO-competent $\mathrm{mDC}$ possess microbicidal activity (Popov et al., 2006, 2008; Von Bergwelt-Baildon et al., 2006) and Nino-Castro, unpublished results). These regulatory DC seem to have at least three critical roles during chronic listeriosis. First, they are involved in the formation and maintenance of the granulomatous structure, second, they keep the pathogen in check, and third, they suppress $\mathrm{T}$ cell effector function that could destroy the granulomatous structure. Therefore, these $\mathrm{DC}_{\text {reg }}$ are essential for the formation and maintenance of this immune priviledged site (Mellor and Munn, 2004) at the same time acting as a barrier that controls bacterial growth and dissemination via an IDO mediated mechanism.

\section{DC $_{\text {reg }}$ ARE IMPORTANT CELLS IN NUMEROUS PARASITICAL INFECTIONS}

Despite their phylogenetic diversity, parasitic protozoans and helminthes have the ability in common to produce long lasting chronic infections (Peters and Sacks, 2006). Understanding how parasitical infections can progress toward chronicification poses a challenge due to the complex host pathogen interactions that depend on the immunological status of the host, but also on the genetic background of both pathogen and host. Some evidence suggests a role for DCs with regulatory function during infection with parasites.

Species of the genus Leishmania are the causing agents of leishmaniases, a group of illnesses of the oral and respiratory mucosae, the skin, and the reticuloendothelium (Reithinger et al., 2007). The cutaneous form is the most common one and is also known to evolve into a chronic disease. Recently, it has been reported in a murine model, that a subset of Langerin ${ }^{+}$Langerhans cells might favor the recruitment of $\mathrm{T}_{\text {reg }}$ cells to the site of infection resulting in aggravated disease. This DC subset was able to promote $\mathrm{T}_{\text {reg }}$ expansion in vitro (Kautz-Neu et al., 2011). Moreover, it has been reported that mice infected with Leishmania major upregulate IDO expression in lymph node $\mathrm{pDCs} \mathrm{IDO}^{+} \mathrm{pDC}$ suppressed $\mathrm{T}$ cell activation and proliferation in vitro. Furthermore, the inhibition of the IDO enzymatic activity resulted in an improvement of the immune response toward L. major manifested by a reduction in lesion size and parasitical burden (Makala et al., 2011). Although IDO has a well-known microbicidal role by limiting pathogen spread via Trp depletion, the evidence in Leishmania infection suggest that in this context $\mathrm{IDO}^{+}$pDCs are deleterious to the host, due to their capacity to attenuate adaptive immune responses. Finally, Nguyen and coworkers reported that infection of murine bone marrow stromal cells by Leishmania donovani enhanced their capacity to attract hematopoietic progenitor cells. L. donovani infected stromal cells were able to support the development DCs from hematopoietic progenitor cells. Moreover, this DC subset acquired regulatory properties being able to suppress $\mathrm{CD}^{+}{ }^{+} \mathrm{T}$ cell proliferation in vitro (Nguyen Hoang et al., 2010). In summary, there is sufficient evidence that different DC populations can acquire regulatory functions in response to Leishmania infection, however their exact role during chronification of the disease is not yet fully understood.

Another example for the involvement of $\mathrm{DC}_{\text {reg }}$ in parasite infections is Chagas disease caused by the parasite Trypanosoma cruzi. In most patients with Chagas disease an immune response develops, the parasitemia wanes, and signs and symptoms resolve completely within a few months. However, around 30\% of the patients will progress toward a chronic disease (Hemmige et al., 2012). The mechanisms that control the progression of the disease into a chronic phase are widely unknown (Sathler-Avelar et al., 2009). Recently, it has been reported that coculture of DCs with T. cruzi trypommastigotes in vitro leads to production of IL10 and TGF $\beta$ by DCs. Furthermore, these cells suppressed T cell proliferation in vitro (Poncini et al., 2008), which indicates that T. cruzi might induce DCs with regulatory functions to evade the host immune system. However, to our knowledge there is no evidence yet supporting the role of $\mathrm{DC}_{\text {reg }}$ as promoters of tolerance toward T. cruzi in infected hosts in vivo. Therefore, the potential role of $\mathrm{DC}_{\text {reg }}$ in the overall immune response against this pathogen remains unclear. Nematode infections are known to promote local immunosuppression in the host, allowing the parasite to achieve a long term survival, which is usually associated with a local chronic infection (Taylor et al., 2005). Recently, Li and coworkers described a naturally occurring DC subset with regulatory activity in the murine infection model of Heligmosoides poligyrus. These CD $11 c^{\text {low }} \mathrm{CD} 45^{\text {mid }} \mathrm{DC}_{\text {reg }}$ expanded rapidly after H. poligyrus infection and promoted $\mathrm{T}_{\mathrm{reg}}$ differentiation in vitro (Li et al., 2011).

Taken together, chronification of infectious diseases is very often accompanied by the induction of DCs with regulatory functions. Reprogramming these APC away from immunostimulatory 
functions seems to be a central theme during the chronification process. However, more work is required to really understand the mechanisms that lead to the observed reprogramming of DCs.

\section{SUMMARY AND CONCLUSIONS}

During the last two decades immunostimulatory functions of DCs were the major focus of DC research (Steinman, 2007) consolidating that these extraordinary cells are the main contributors for immune activation. However, during the last years accumulating evidence strongly suggests that DCs are much more versatile in their functions allowing them to regulate $\left(\mathrm{DC}_{\mathrm{reg}}\right)$ or even halt immune responses e.g., by inducing tolerance (tolerogenic DC). $\mathrm{DC}_{\text {reg }}$ are implicated in terminating inflammatory responses under physiological conditions yet regulatory DC functions also seem to be hijacked by pathologic conditions as different as cancer or chronic infection. While several of the molecules associated with regulatory DC function (IL-10, TGF $\beta$, IDO, PGE 2 , and CD25) have been elucidated and observed in numerous cancer entities and chronic infections, the molecular mechanisms reprogramming $\mathrm{DC}$ to become $\mathrm{DC}_{\text {reg }}$ are still poorly understood. Many previous studies are rather descriptive and many findings in murine and rodent models often could not be translated to the human, leaving researchers confronted with the problem to investigate molecular mechanisms of $\mathrm{DC}_{\text {reg }}$ involvement

\section{REFERENCES}

Aalamian, M., Pirtskhalaishvili, G., Nunez, A., Esche, C., Shurin, G. V., Huland, E., Huland, H., and Shurin, M. R. (2001). Human prostate cancer regulates generation and maturation of monocyte-derived dendritic cells. Prostate 46, 68-75.

Akbari, O., Dekruyff, R. H., and Umetsu, D. T. (2001). Pulmonary dendritic cells producing IL-10 mediate tolerance induced by respiratory exposure to antigen. Nat. Immunol. 2, 725-731.

Aliberti, J., Hieny, S., Reis E Sousa, C., Serhan, C. N., and Sher, A. (2002). Lipoxin-mediated inhibition of IL12 production by DCs: a mechanism for regulation of microbial immunity. Nat. Immunol. 3, 76-82.

Allerberger, F., and Wagner, M. (2010). Listeriosis: a resurgent foodborne infection. Clin. Microbiol. Infect. 16, $16-23$.

Almand, B., Resser, J. R., Lindman, B., Nadaf, S., Clark, J. I., Kwon, E. D., Carbone, D. P., and Gabrilovich, D. I. (2000). Clinical significance of defective dendritic cell differentiation in cancer. Clin. Cancer Res. 6, 1755-1766.

Arce, F., Breckpot, K., Stephenson, H., Karwacz, K., Ehrenstein, M. R., Collins, M., and Escors, D. (2011). Selective ERK activation differentiates mouse and human tolerogenic

in human specimens. However, the availability of sequencingbased genomic technologies assessing networks of epigenetic, transcriptional, and translational regulation on a genome-wide scale and in an unprecedented resolution makes research into human $\mathrm{DC}_{\text {reg }}$ biology a very promising endeavor. We envision that the integration of such data will allow us in the future to better understand how exogenous signals are integrated in DCs to foster a regulatory rather than an immunostimulatory program. Moreover, signal integration is not only restricted to classical pro- and anti-inflammatory mediators but is further altered by a myriad of soluble and cell-contact mediated signals as exemplified here for metabolites like kynurenines or unsaturated fatty acids. Moreover, understanding $\mathrm{DC}_{\mathrm{reg}}$ biology will also guide the development of better DC-based vaccines, e.g., as cancer immunotherapy. Unraveling differential and context-dependent signal integration by DCs during activation will also lead to the discovery of genes that could be targeted for immunomodulation.

\section{ACKNOWLEDGMENTS}

This review is support by the research grants SFB832 (Molecular basis and modulation of cellular interactions in the tumor microenvironment) and SFB704 (Molecular mechanisms and Chemical Modulation of Local Immune Regulation) granted by the German Research Council.

Crohn's disease. Clin. Nutr. doi: 10.1016/j.clnu.2012.03.002. [Epub ahead of print].

Belladonna, M. L., Volpi, C., Bianchi, R., Vacca, C., Orabona, C., Pallotta, M. T., Boon, L., Gizzi, S., Fioretti, M. C., Grohmann, U., and Puccetti, P. (2008). Cutting edge: autocrine TGF-beta sustains default tolerogenesis by IDO-competent dendritic cells. J. Immunol. 181, 5194-5198.

Benoit, V., Relic, B., Leval Xd, X. Chariot, A., Merville, M. P., and Bours, V. (2004). Regulation of HER-2 oncogene expression by cyclooxygenase- 2 and prostaglandin E2. Oncogene 23, 1631-1635.

Bharadwaj, U., Li, M., Zhang, R., Chen, C., and Yao, Q. (2007). Elevated interleukin-6 and G-CSF in human pancreatic cancer cell conditioned medium suppress dendritic cell differentiation and activation. Cancer Res. 67, 5479-5488.

Blanco, P., Palucka, A. K., Gill, M., Pascual, V., and Banchereau, J. (2001). Induction of dendritic cell differentiation by IFN-alpha in systemic lupus erythematosus. Science 294, 1540-1543.

Blank, S. E., Johnson, E. C., Weeks, D. K., and Wysham, C. H. (2010). Circulating dendritic cell number and intracellular TNF-alpha production in women with type
2 diabetes. Acta Diabetol. doi: 10.1007/s00592-010-0190-8. [Epub ahead of print].

Blok, W. L., De Bruijn, M. F., Leenen, P. J., Eling, W. M., Van Rooijen, N., Stanley, E. R., Buurman, W. A., and Van Der Meer, J. W. (1996). Dietary n-3 fatty acids increase spleen size and postendotoxin circulating TNF in mice; role of macrophages, macrophage precursors, and colony-stimulating factor1. J. Immunol. 157, 5569-5573.

Bogunovic, M., Ginhoux, F., Helft, J., Shang, L., Hashimoto, D., Greter, M., Liu, K., Jakubzick, C., Ingersoll, M. A., Leboeuf, M., Stanley, E. R., Nussenzweig, M., Lira, S. A., Randolph, G. J., and Merad, M. (2009). Origin of the lamina propria dendritic cell network. Immunity 31, 513-525.

Bonnotte, B., Crittenden, M., Larmonier, N., Gough, M., and Vile, R. G. (2004). MIP-3alpha transfection into a rodent tumor cell line increases intratumoral dendritic cell infiltration but enhances (facilitates) tumor growth and decreases immunogenicity. $J$. Immunol. 173, 4929-4935.

Calder, P. C. (1997). n-3 polyunsaturated fatty acids and cytokine production in health and disease. Ann. Nutr. Metab. 41, 203-234. 
Caughey, G. E., Mantzioris, E., Gibson, R. A., Cleland, L. G., and James, M. J. (1996). The effect on human tumor necrosis factor alpha and interleukin 1 beta production of diets enriched in n-3 fatty acids from vegetable oil or fish oil. Am. J. Clin. Nutr. 63, 116-122.

Cella, M., Jarrossay, D., Facchetti, F., Alebardi, O., Nakajima, H., Lanzavecchia, A., and Colonna, M. (1999). Plasmacytoid monocytes migrate to inflamed lymph nodes and produce large amounts of type I interferon. Nat. Med. 5, 919-923.

Chaux, P., Favre, N., Martin, M., and Martin, F. (1997). Tumorinfiltrating dendritic cells are defective in their antigen-presenting function and inducible B7 expression in rats. Int. J. Cancer 72, 619-624.

Chawla, A., Nguyen, K. D., and Goh, Y. P. (2011). Macrophage-mediated inflammation in metabolic disease. Nat. Rev. Immunol. 11, 738-749.

Chemnitz, J. M., Driesen, J., Classen, S., Riley, J. L., Debey, S., Beyer, M., Popov, A., Zander, T., and Schultze, J. L. (2006). Prostaglandin E2 impairs CD4+ T cell activation by inhibition of lck: implications in Hodgkin's lymphoma. Cancer Res. 66, 1114-1122.

Chentoufi, A. A., Dervillez, X., Dasgupta, G., Nguyen, C., Kabbara, K. W., Jiang, X., Nesburn, A. B., Wechsler, S. L., and Benmohamed, L. (2012). The herpes simplex virus type 1 latency-associated transcript inhibits phenotypic and functional maturation of dendritic cells. Viral Immunol. 25, 204-215.

Cheong, C., Matos, I., Choi, J. H., Dandamudi, D. B., Shrestha, E., Longhi, M. P., Jeffrey, K. L., Anthony, R. M., Kluger, C., Nchinda, G., Koh, H., Rodriguez, A., Idoyaga, J., Pack, M., Velinzon, K., Park, C. G., and Steinman, R. M. (2010). Microbial stimulation fully differentiates monocytes to DC-SIGN/CD209(+) dendritic cells for immune $\mathrm{T}$ cell areas. Cell 143, 416-429.

Chinetti, G., Fruchart, J. C., and Staels, B. (2000). Peroxisome proliferatoractivated receptors (PPARs): nuclear receptors at the crossroads between lipid metabolism and inflammation. Inflamm. Res. 49, 497-505.

Chung, D. J., Rossi, M., Romano, E., Ghith, J., Yuan, J., Munn, D. H., and Young, J. W. (2009). Indoleamine 2, 3-dioxygenase-expressing mature human monocyte-derived dendritic cells expand potent autologous regulatory $\mathrm{T}$ cells. Blood 114, 555-563.

Corrales, J. J., Almeida, M., Burgo, R. M., Hernandez, P., Miralles, J. M., and Orfao, A. (2007). Decreased production of inflammatory cytokines by circulating monocytes and dendritic cells in type 2 diabetic men with atherosclerotic complications. J. Diabetes Complications 21, 41-49.

Dall'Era, M., and Davis, J. (2004). CTLA4Ig: a novel inhibitor of costimulation. Lupus 13, 372-376.

De Batlle, J., Sauleda, J., Balcells, E., Gomez, F. P., Mendez, M., Rodriguez, E., Barreiro, E., Ferrer, J. J., Romieu, I., Gea, J., Anto, J. M., and Garcia-Aymerich, J. (2011). Association between Omega3 and Omega6 fatty acid intakes and serum inflammatory markers in COPD. J. Nutr. Biochem. 23, 817-821.

De Smedt, T., Van Mechelen, M., De Becker, G., Urbain, J., Leo, O., and Moser, M. (1997). Effect of interleukin-10 on dendritic cell maturation and function. Eur. J. Immunol. 27, 1229-1235.

Del Rio, M. L., Bernhardt, G., Rodriguez-Barbosa, J. I., and Forster, R. (2010). Development and functional specialization of CD103+ dendritic cells. Immunol. Rev. 234, 268-281.

Dental, C., Florentin, J., Aouar, B., Gondois-Rey, F., Durantel, D., Baumert, T. F., Nunes, J. A., Olive, D., Hirsch, I., and Stranska, R. (2012). Hepatitis C virus fails to activate NF-kappaB signaling in plasmacytoid dendritic cells. $J$. Virol. 86, 1090-1096.

Di Domizio, J., Blum, A., GallagherGambarelli, M., Molens, J. P., Chaperot, L., and Plumas, J. (2009). TLR7 stimulation in human plasmacytoid dendritic cells leads to the induction of early IFN-inducible genes in the absence of type I IFN. Blood 114, 1794-1802.

Doyen, V., Rubio, M., Braun, D., Nakajima, T., Abe, J., Saito, H., Delespesse, G., and Sarfati, M. (2003). Thrombospondin 1 is an autocrine negative regulator of human dendritic cell activation. $J$. Exp. Med. 198, 1277-1283.

Draper, E., Reynolds, C. M., Canavan, M., Mills, K. H., Loscher, C. E., and Roche, H. M. (2011). Omega-3 fatty acids attenuate dendritic cell function via NF-kappaB independent of PPARgamma. J. Nutr. Biochem. 22, 784-790.

Driesen, J., Popov, A., and Schultze, J. L. (2008). CD25 as an immune regulatory molecule expressed on myeloid dendritic cells. Immunobiology 213 , 849-858.

Duffaut, C., Galitzky, J., Lafontan, M., and Bouloumie, A. (2009). Unexpected trafficking of immune cells within the adipose tissue during the onset of obesity. Biochem. Biophys. Res. Commun. 384 , 482-485.

Dumitriu, I. E., Dunbar, D. R., Howie, S. E., Sethi, T., and Gregory, C. D. (2009). Human dendritic cells produce TGF-beta 1 under the influence of lung carcinoma cells and prime the differentiation of $\mathrm{CD} 4+\mathrm{CD} 25+\mathrm{Foxp} 3+$ regulatory $\mathrm{T}$ cells. J. Immunol. 182, 2795-2807.

Dzionek, A., Sohma, Y., Nagafune, J., Cella, M., Colonna, M., Facchetti, F., Gunther, G., Johnston, I., Lanzavecchia, A., Nagasaka, T., Okada, T., Vermi, W., Winkels, G., Yamamoto, T., Zysk, M., Yamaguchi, Y., and Schmitz, J. (2001). BDCA-2, a novel plasmacytoid dendritic cell-specific type II C-type lectin, mediates antigen capture and is a potent inhibitor of interferon alpha/beta induction. J. Exp. Med. 194, 1823-1834.

Fallarino, F., Vacca, C., Orabona, C., Belladonna, M. L., Bianchi, R., Marshall, B., Keskin, D. B., Mellor, A. L., Fioretti, M. C. Grohmann, U., and Puccetti, P. (2002). Functional expression of indoleamine 2, 3-dioxygenase by murine CD8 alpha(+) dendritic cells. Int. Immunol. 14, 65-68.

Ferrero, E., Bondanza, A., Leone, B. E., Manici, S., Poggi, A., and Zocchi, M. R. (1998). CD14+ CD34+ peripheral blood mononuclear cells migrate across endothelium and give rise to immunostimulatory dendritic cells. J. Immunol. 160, 2675-2683.

Gabrilovich, D. (2004). Mechanisms and functional significance of tumour-induced dendritic-cell defects. Nat. Rev. Immunol. 4, 941-952.

Gabrilovich, D. I., Ostrand-Rosenberg, S., and Bronte, V. (2012). Coordinated regulation of myeloid cells by tumours. Nat. Rev. Immunol. 12, 253-268.

Gehrie, E., Van Der Touw, W., Bromberg, J. S., and Ochando, J. C. (2011). Plasmacytoid dendritic cells in tolerance. Methods Mol. Biol. 677, 127-147.

Ghiringhelli, F., Puig, P. E., Roux, S., Parcellier, A., Schmitt, E., Solary, E., Kroemer, G., Martin, F., Chauffert, B., and Zitvogel, L. (2005). Tumor cells convert immature myeloid dendritic cells into
TGF-beta-secreting cells inducing CD4+CD25+ regulatory $\mathrm{T}$ cell proliferation. J. Exp. Med. 202, 919-929.

Ghosh, D., and Branch, M. (1975). Triamterene and mouse liver tryptophan pyrrolase: possible activation of cytosol by the pteridine in enhancing enzymic activity. Acta Vitaminol. Enzymol. 29, 294-298.

Gray, M. L., and Killinger, A. H. (1966). Listeria monocytogenes and listeric infections. Bacteriol. Rev. 30, 309-382.

Grohmann, U., Orabona, C., Fallarino, F., Vacca, C., Calcinaro, F., Falorni, A., Candeloro, P., Belladonna, M. L., Bianchi, R., Fioretti, M. C., and Puccetti, P. (2002). CTLA-4-Ig regulates tryptophan catabolism in vivo. Nat. Immunol. 3, 1097-1101.

Hansen, D., Dendale, P., Beelen, M., Jonkers, R. A., Mullens, A., Corluy, L., Meeusen, R., and Van Loon, L. J. (2010). Plasma adipokine and inflammatory marker concentrations are altered in obese, as opposed to non-obese, type 2 diabetes patients. Eur. J. Appl. Physiol. 109, 397-404.

Harman, A. N., Lai, J., Turville, S., Samarajiwa, S., Gray, L., Marsden, V., Mercier, S. K., Jones, K., Nasr, N., Rustagi, A., Cumming, H., Donaghy, H., Mak, J., Gale, M. Jr., Churchill, M., Hertzog, P., and Cunningham, A. L. (2011). HIV infection of dendritic cells subverts the IFN induction pathway via IRF-1 and inhibits type 1 IFN production. Blood 118, 298-308.

Hartmann, E., Wollenberg, B., Rothenfusser, S., Wagner, M., Wellisch, D., Mack, B., Giese, T., Gires, O., Endres, S., and Hartmann, G. (2003). Identification and functional analysis of tumor-infiltrating plasmacytoid dendritic cells in head and neck cancer. Cancer Res. 63, 6478-6487.

Hauben, E., Gregori, S., Draghici, E., Migliavacca, B., Olivieri, S., Woisetschlager, M., and Roncarolo, M. G. (2008). Activation of the aryl hydrocarbon receptor promotes allograft-specific tolerance through direct and dendritic cell-mediated effects on regulatory $\mathrm{T}$ cells. Blood $112,1214-1222$.

Hemmige, V., Tanowitz, H., and Sethi, A. (2012). Trypanosoma cruzi infection: a review with emphasis on cutaneous manifestations. Int. J. Dermatol. 51, 501-508.

Hemmi, H., and Akira, S. (2005). TLR signalling and the function of dendritic cells. Chem. Immunol. Allergy 86, 120-135. 
Hendrich, S. (2010). (n-3) Fatty acids: clinical trials in people with type 2 diabetes. Adv. Nutr. 1, 3-7.

Herber, D. L., Cao, W., Nefedova, Y., Novitskiy, S. V., Nagaraj, S., Tyurin, V. A., Corzo, A., Cho, H. I., Celis, E., Lennox, B., Knight, S. C., Padhya, T., McCaffrey, T. V., McCaffrey, J. C., Antonia, S., Fishman, M., Ferris, R. L., Kagan, V. E., and Gabrilovich, D. I. (2010). Lipid accumulation and dendritic cell dysfunction in cancer. Nat. Med. 16, 880-886.

Huang, X., Stenvinkel, P., Qureshi, A. R., Riserus, U., Cederholm, T., Barany, P., Heimburger, O., Lindholm, B., and Carrero, J. J. (2012). Essential polyunsaturated fatty acids, inflammation and mortality in dialysis patients. Nephrol. Dial. Transplant. doi: 10.1093/ndt/gfs132. [Epub ahead of print].

Iliev, I. D., Spadoni, I., Mileti, E., Matteoli, G., Sonzogni, A., Sampietro, G. M., Foschi, D., Caprioli, F., Viale, G., and Rescigno, M. (2009). Human intestinal epithelial cells promote the differentiation of tolerogenic dendritic cells. Gut 58, 1481-1489.

Iweala, O. I., and Nagler, C. R. (2006). Immune privilege in the gut: the establishment and maintenance of non-responsiveness to dietary antigens and commensal flora. Immunol. Rev. 213, 82-100.

Janeway, C. A. Jr., and Medzhitov, R. (2002). Innate immune recognition. Annu. Rev. Immunol. 20, 197-216.

Jin, O., Kavikondala, S., Mok, M. Y., Sun, L., Gu, J., Fu, R., Chan, A., Yeung, J., Nie, Y., and Lau, C. S. (2010). Abnormalities in circulating plasmacytoid dendritic cells in patients with systemic lupus erythematosus. Arthritis Res. Ther. 12, R137.

Jonuleit, H., Schmitt, E., Schuler, G., Knop, J., and Enk, A. H. (2000). Induction of interleukin 10-producing, nonproliferating $\mathrm{CD} 4(+) \mathrm{T}$ cells with regulatory properties by repetitive stimulation with allogeneic immature human dendritic cells. J. Exp. Med. 192, 1213-1222.

Kalergis, A. M., Iruretagoyena, M. I., Barrientos, M. J., Gonzalez, P. A., Herrada, A. A., Leiva, E. D., Gutierrez, M. A., Riedel, C. A., Bueno, S. M., and Jacobelli, S. H. (2009). Modulation of nuclear factor-kappaB activity can influence the susceptibility to systemic lupus erythematosus. Immunology 128, e306-e314.
Kalinski, P. (2012). Regulation of immune responses by prostaglandin E2. J. Immunol. 188, 21-28.

Kalinski, P., Hilkens, C. M., Snijders, A., Snijdewint, F. G., and Kapsenberg, M. L. (1997). IL-12-deficient dendritic cells, generated in the presence of prostaglandin E2, promote type 2 cytokine production in maturing human naive $\mathrm{T}$ helper cells. J. Immunol. 159, 28-35.

Kalinski, P., Vieira, P. L., Schuitemaker, J. H., De Jong, E. C., and Kapsenberg, M. L. (2001). Prostaglandin E(2) is a selective inducer of interleukin-12 p40 (IL-12p40) production and an inhibitor of bioactive IL-12p70 heterodimer. Blood 97, 3466-3469.

Kang, H. K., Liu, M., and Datta, S. K. (2007). Low-dose peptide tolerance therapy of lupus generates plasmacytoid dendritic cells that cause expansion of autoantigenspecific regulatory $\mathrm{T}$ cells and contraction of inflammatory Th17 cells. J. Immunol. 178, 7849-7858.

Kather, A., Raftery, M. J., Devi-Rao, G., Lippmann, J., Giese, T., SandriGoldin, R. M., and Schonrich, G. (2010). Herpes simplex virus type 1 (HSV-1)-induced apoptosis in human dendritic cells as a result of downregulation of cellular FLICEinhibitory protein and reduced expression of HSV-1 antiapoptotic latency-associated transcript sequences. J. Virol. 84, 1034-1046.

Kautz-Neu, K., Noordegraaf, M., Dinges, S., Bennett, C. L., John, D., Clausen, B. E., and Von Stebut, E. (2011). Langerhans cells are negative regulators of the antiLeishmania response. J. Exp. Med. 208, 885-891.

Kavousanaki, M., Makrigiannakis, A., Boumpas, D., and Verginis, P. (2010). Novel role of plasmacytoid dendritic cells in humans: induction of interleukin-10-producing Treg cells by plasmacytoid dendritic cells in patients with rheumatoid arthritis responding to therapy. Arthritis Rheum. 62, 53-63.

Kim, H. S., Zhang, X., and Choi, Y. S. (1994). Activation and proliferation of follicular dendritic cell-like cells by activated $\mathrm{T}$ lymphocytes. $J$. Immunol. 153, 2951-2961.

Ko, H. J., Cho, M. L., Lee, S. Y., Oh, H. J., Heo, Y. J., Moon, Y. M., Kang, C. M., Kwok, S. K., Ju, J. H., Park, S. H., Park, K. S., and Kim, H. Y. (2010). CTLA4-Ig modifies dendritic cells from mice with collageninduced arthritis to increase the CD4+CD25+Foxp3+ regulatory $\mathrm{T}$ cell population. J. Autoimmun. 34, 111-120.
Krempski, J., Karyampudi, L., Behrens, M. D., Erskine, C. L., Hartmann, L., Dong, H., Goode, E. L., Kalli K. R., and Knutson, K. L. (2011). Tumor-infiltrating programmed death receptor-1+ dendritic cells mediate immune suppression in ovarian cancer. J. Immunol. 186 6905-6913.

Kruse, M., Rosorius, O., Kratzer, F. Stelz, G., Kuhnt, C., Schuler, G. Hauber, J., and Steinkasserer, A. (2000). Mature dendritic cells infected with herpes simplex virus type 1 exhibit inhibited T-cell stimulatory capacity. J. Virol. 74 , 7127-7136.

Laffont, S., Siddiqui, K. R., and Powrie, F. (2010). Intestinal inflammation abrogates the tolerogenic properties of MLN CD103+ dendritic cells. Eur. J. Immunol. 40, 1877-1883.

Lai, W. K., Curbishley, S. M., Goddard, S., Alabraba, E., Shaw, J., Youster, J., McKeating, J., and Adams, D. H. (2007). Hepatitis C is associated with perturbation of intrahepatic myeloid and plasmacytoid dendritic cell function. J. Hepatol. 47, 338-347.

Lande, R., Gregorio, J., Facchinetti, V., Chatterjee, B., Wang, Y. H., Homey, B., Cao, W., Su, B., Nestle, F. O. Zal, T., Mellman, I., Schroder, J. M., Liu, Y. J., and Gilliet, M. (2007) Plasmacytoid dendritic cells sense self-DNA coupled with antimicrobial peptide. Nature 449, 564-569.

Laouar, Y., Town, T., Jeng, D., Tran, E., Wan, Y., Kuchroo, V. K., and Flavell, R. A. (2008). TGF-beta signaling in dendritic cells is a prerequisite for the control of autoimmune encephalomyelitis. Proc. Natl. Acad. Sci. U.S.A. 105, 10865-10870.

Lee, I. Y., and Choe, J. (2003). Human follicular dendritic cells and fibroblasts share the 3C8 antigen. Biochem. Biophys. Res. Commun. 304, 701-707.

Lee, P. Y., Weinstein, J. S., Nacionales, D. C., Scumpia, P. O., Li, Y., Butfiloski, E., Van Rooijen, N., Moldawer, L., Satoh, M., and Reeves, W. H. (2008). A novel type I IFN-producing cell subset in murine lupus. J. Immunol. 180, 5101-5108.

Legler, D. F., Krause, P., Scandella, E., Singer, E., and Groettrup, M. (2006). Prostaglandin E2 is generally required for human dendritic cell migration and exerts its effect via EP2 and EP4 receptors. J. Immunol. 176, 966-973.

Li, M. O., and Flavell, R. A. (2008). Contextual regulation of inflammation: a duet by transforming growth factor-beta and interleukin10. Immunity $28,468-476$.
Li, Z., Liu, G., Chen, Y., Liu, Y., Liu, B., and Su, Z. (2011). The phenotype and function of naturally existing regulatory dendritic cells in nematode-infected mice. Int. J. Parasitol. 41, 1129-1137.

Lindhout, E., Van Eijk, M., Van Pel, M., Lindeman, J., Dinant, H. J., and De Groot, C. (1999). Fibroblast-like synoviocytes from rheumatoid arthritis patients have intrinsic properties of follicular dendritic cells. J. Immunol. 162, 5949-5956.

Liu, Q., Zhang, C., Sun, A., Zheng, Y., Wang, L., and Cao, X. (2009). Tumor-educated CD11bhighIalow regulatory dendritic cells suppress $\mathrm{T}$ cell response through arginase I. $J$. Immunol. 182, 6207-6216.

Loscher, C. E., Draper, E., Leavy, O., Kelleher, D., Mills, K. H., and Roche, H. M. (2005). Conjugated linoleic acid suppresses NF-kappa B activation and IL-12 production in dendritic cells through ERK-mediated IL-10 induction. J. Immunol. 175, 4990-4998.

Lumeng, C. N., and Saltiel, A. R. (2011). Inflammatory links between obesity and metabolic disease. $J$. Clin. Invest. 121, 2111-2117.

Lutz, M. B. (2012). Therapeutical potential of semi-mature dendritic cells for tolerance induction. Front. Immunol. 3:123. doi: 10.3389/fimmu.2012.00123

Lund, J., Sato, A., Akira, S., Medzhitov, R., and Iwasaki, A. (2003). Toll-like receptor 9-mediated recognition of Herpes simplex virus-2 by plasmacytoid dendritic cells. J. Exp. Med. 198, 513-520

Lutz, M. B., Kukutsch, N. A., Menges, M., Rossner, S., and Schuler, G. (2000). Culture of bone marrow cells in GM-CSF plus high doses of lipopolysaccharide generates exclusively immature dendritic cells which induce alloantigen-specific CD4 $\mathrm{T}$ cell anergy in vitro. Eur. J. Immunol. 30, 1048-1052.

Lutz, M. B., and Schuler, G. (2002). Immature, semi-mature and fully mature dendritic cells: which signals induce tolerance or immunity? Trends Immunol. 23, 445-449.

Ma, Y., Shurin, G. V., Gutkin, D. W. and Shurin, M. R. (2012). Tumor associated regulatory dendritic cells. Semin. Cancer Biol. 22, 298-306.

Makala, L. H., Baban, B., Lemos, H. El-Awady, A. R., Chandler, P. R. Hou, D. Y., Munn, D. H., and Mellor, A. L. (2011). Leishmania major attenuates host immunity by stimulating local indoleamine 2, 3dioxygenase expression. J. Infect. Dis. 203, 715-725. 
Manicassamy, S., and Pulendran, B. (2011). Dendritic cell control of tolerogenic responses. Immunol. Rev. 241, 206-227.

Martinson, J. A., Roman-Gonzalez, A., Tenorio, A. R., Montoya, C. J., Gichinga, C. N., Rugeles, M. T., Tomai, M., Krieg, A. M., Ghanekar, S., Baum, L. L., and Landay, A. L. (2007). Dendritic cells from HIV-1 infected individuals are less responsive to toll-like receptor (TLR) ligands. Cell Immunol. 250, 75-84.

Matta, B. M., Raimondi, G., Rosborough, B. R., Sumpter, T. L., and Thomson, A. W. (2012). IL-27 production and STAT3dependent upregulation of $\mathrm{B} 7-\mathrm{H} 1$ mediate immune regulatory functions of liver plasmacytoid dendritic cells. J. Immunol. 188, 5227-5237.

Mattacks, C. A., Sadler, D., and Pond, C. M. (2004). The effects of dietary lipids on dendritic cells in perinodal adipose tissue during chronic mild inflammation. Br. J. Nutr. 91, 883-892.

McGee-Lawrence, M. E., McClearyWheeler, A. L., Secreto, F. J., Razidlo, D. F., Zhang, M., Stensgard, B. A., Li, X., Stein, G. S., Lian, J. B., and Westendorf, J. J. (2011). Suberoylanilide hydroxamic acid (SAHA; vorinostat) causes bone loss by inhibiting immature osteoblasts. Bone 48, 1117-1126.

Means, T. K., Latz, E., Hayashi, F., Murali, M. R., Golenbock, D. T., and Luster, A. D. (2005). Human lupus autoantibody-DNA complexes activate $\mathrm{DCs}$ through cooperation of CD32 and TLR9. J. Clin. Invest. 115, 407-417.

Melki, M. T., Saidi, H., Dufour, A., Olivo-Marin, J. C., and Gougeon, M. L. (2010). Escape of HIV-1-infected dendritic cells from TRAIL-mediated NK cell cytotoxicity during NK-DC crosstalk-a pivotal role of HMGB1. PLoS Pathog. 6:e1000862. doi: 10.1371/journal.ppat. 1000862

Mellor, A. L., and Munn, D. H. (2004). IDO expression by dendritic cells: tolerance and tryptophan catabolism. Nat. Rev. Immunol. 4, 762-774.

Mezrich, J. D., Fechner, J. H., Zhang, X., Johnson, B. P., Burlingham, W. J., and Bradfield, C. A. (2010). An interaction between kynurenine and the aryl hydrocarbon receptor can generate regulatory $\mathrm{T}$ cells. $\mathrm{J}$. Immunol. 185, 3190-3198.

Michielsen, A. J., Hogan, A. E., Marry, J., Tosetto, M., Cox, F., Hyland, J. M., Sheahan, K. D., O'Donoghue, D. P., Mulcahy, H. E., Ryan, E. J., and O'Sullivan, J. N. (2011).
Tumour tissue microenvironment can inhibit dendritic cell maturation in colorectal cancer. PLoS ONE 6:e27944. doi: 10.1371/journal.pone.0027944

Miyake, T., Akbar, S. M., Yoshida, O., Chen, S., Hiasa, Y., Matsuura, B., Abe, M., and Onji, M. (2010). Impaired dendritic cell functions disrupt antigen-specific adaptive immune responses in mice with nonalcoholic fatty liver disease. $J$. Gastroenterol. 45, 859-867.

Mook, P., Patel, B., and Gillespie, I. A. (2011). Risk factors for mortality in non-pregnancy-related listeriosis. Epidemiol. Infect. 140, 706-715.

Moore, K. W., De Waal Malefyt, R., Coffman, R. L., and O'Garra, A. (2001). Interleukin-10 and the interleukin-10 receptor. Annu. Rev. Immunol. 19, 683-765.

Morelli, A. E., Larregina, A. T., Shufesky, W. J., Zahorchak, A. F., Logar, A. J., Papworth, G. D., Wang, Z., Watkins, S. C., Falo, L. D. Jr., and Thomson, A. W. (2003). Internalization of circulating apoptotic cells by splenic marginal zone dendritic cells: dependence on complement receptors and effect on cytokine production. Blood 101, 611-620.

Munder, M. (2009). Arginase: an emerging key player in the mammalian immune system. Br. J. Pharmacol. 158, 638-651.

Munn, D. H., and Mellor, A. L. (2007). Indoleamine 2, 3-dioxygenase and tumor-induced tolerance. J. Clin. Invest. 117, 1147-1154.

Muthuswamy, R., Mueller-Berghaus, J., Haberkorn, U., Reinhart, T. A., Schadendorf, D., and Kalinski, P. (2010). PGE(2) transiently enhances DC expression of CCR7 but inhibits the ability of DCs to produce CCL19 and attract naive T cells. Blood 116, 1454-1459.

Nencioni, A., Grunebach, F., Zobywlaski, A., Denzlinger, C., Brugger, W., and Brossart, P. (2002). Dendritic cell immunogenicity is regulated by peroxisome proliferator-activated receptor gamma. J. Immunol. 169, 1228-1235.

Nestle, F. O., Conrad, C., Tun-Kyi, A., Homey, B., Gombert, M., Boyman, O., Burg, G., Liu, Y. J., and Gilliet, M. (2005). Plasmacytoid predendritic cells initiate psoriasis through interferon-alpha production. J. Exp. Med. 202, 135-143.

Nguyen Hoang, A. T., Liu, H., Juarez, J., Aziz, N., Kaye, P. M., and Svensson, M. (2010). Stromal cell-derived CXCL12 and CCL8 cooperate to support increased development of regulatory dendritic cells following Leishmania infection. J. Immunol. 185, 2360-2371.

Norian, L. A., Rodriguez, P. C., O’Mara, L. A., Zabaleta, J., Ochoa, A. C. Cella, M., and Allen, P. M. (2009). Tumor-infiltrating regulatory dendritic cells inhibit CD8+ $\mathrm{T}$ cell function via L-arginine metabolism. Cancer Res. 69, 3086-3094.

Pacanowski, J., Kahi, S., Baillet, M., Lebon, P., Deveau, C., Goujard, C., Meyer, L., Oksenhendler, E., Sinet, M., and Hosmalin, A. (2001) Reduced blood CD123+ (lymphoid) and CD11c+ (myeloid) dendritic cell numbers in primary HIV-1 infection. Blood 98, 3016-3021.

Paietta, E., Racevskis, J., Neuberg, D., Rowe, J. M., Goldstone, A. H., and Wiernik, P. H. (1997). Expression of CD25 (interleukin-2 receptor alpha chain) in adult acute lymphoblastic leukemia predicts for the presence of BCR/ABL fusion transcripts: results of a preliminary laboratory analysis of ECOG/MRC Intergroup Study E2993. Eastern Cooperative Oncology Group/Medical Research Council. Leukemia 11, 1887-1890.

Palucka, K., and Banchereau, J. (2012). Cancer immunotherapy via dendritic cells. Nat. Rev. Cancer. 12, 265-277.

Penna, G., and Adorini, L. (2000). 1 Alpha, 25-dihydroxyvitamin D3 inhibits differentiation, maturation, activation, and survival of dendritic cells leading to impaired alloreactive $\mathrm{T}$ cell activation. J. Immunol. 164 2405-2411.

Peters, N., and Sacks, D. (2006). Immune privilege in sites of chronic infection: Leishmania and regulatory T cells. Immunol. Rev. 213, 159-179.

Piemonti, L., Monti, P., Sironi, M., Fraticelli, P., Leone, B. E., Dal Cin, E., Allavena, P., and Di Carlo, V. (2000). Vitamin D3 affects differentiation, maturation, and function of human monocyte-derived dendritic cells. J. Immunol. 164, 4443-4451.

Pletinckx, K., Dohler, A., Pavlovic, V., and Lutz, M. B. (2011). Role of dendritic cell maturity/costimulation for generation, homeostasis, and suppressive activity of regulatory T cells. Front. Immunol. 2:39. doi: 10.3389/fimmu.2011.00039

Poncini, C. V., Alba Soto, C. D., Batalla, E., Solana, M. E., and Gonzalez Cappa, S. M. (2008). Trypanosoma cruzi induces regulatory dendritic cells in vitro. Infect. Immun. 76 , 2633-2641.

Popov, A., Abdullah, Z., Wickenhauser, C., Saric, T., Driesen, J., Hanisch,
F. G., Domann, E., Raven, E. L., Dehus, O., Hermann, C., Eggle, D., Debey, S., Chakraborty, T., Kronke, M., Utermohlen, O., and Schultze, J. L. (2006). Indoleamine 2, 3-dioxygenase-expressing dendritic cells form suppurative granulomas following Listeria monocytogenes infection. J. Clin. Invest. 116, 3160-3170.

Popov, A., Driesen, J., Abdullah, Z., Wickenhauser, C., Beyer M., Debey-Pascher, S., Saric, T., Kummer, S., Takikawa, O., Domann, E., Chakraborty, T., Kronke, M., Utermohlen, O., and Schultze, J. L. (2008). Infection of myeloid dendritic cells with Listeria monocytogenes leads to the suppression of $\mathrm{T}$ cell function by multiple inhibitory mechanisms. $J$. Immunol. 181, 4976-4988.

Popov, A., and Schultze, J. L. (2008). IDO-expressing regulatory dendritic cells in cancer and chronic infection. J. Mol. Med. (Berl.) 86, 145-160.

Ramakrishnan, L. (2012). Revisiting the role of the granuloma in tuberculosis. Nat. Rev. Immunol. 12, 352-366.

Reis e Sousa, C. (2006). Dendritic cells in a mature age. Nat. Rev. Immunol. 6, 476-483.

Reithinger, R., Dujardin, J. C., Louzir, H., Pirmez, C., Alexander, B., and Brooker, S. (2007). Cutaneous leishmaniasis. Lancet Infect. Dis. 7, 581-596.

Riol-Blanco, L., Sanchez-Sanchez, N. Torres, A., Tejedor, A., Narumiya, S., Corbi, A. L., Sanchez-Mateos, P., and Rodriguez-Fernandez, J. L. (2005). The chemokine receptor CCR7 activates in dendritic cells two signaling modules that independently regulate chemotaxis and migratory speed. J. Immunol. 174, 4070-4080.

Rodriguez, P. C., Quiceno, D. G., and Ochoa, A. C. (2007). L-arginine availability regulates T-lymphocyte cell-cycle progression. Blood 109, 1568-1573.

Rodriguez, P. C., Quiceno, D. G., Zabaleta, J., Ortiz, B., Zea, A H., Piazuelo, M. B., Delgado, A., Correa, P., Brayer, J., Sotomayor, E. M., Antonia, S., Ochoa, J. B., and Ochoa, A. C. (2004). Arginase I production in the tumor microenvironment by mature myeloid cells inhibits T-cell receptor expression and antigen-specific T-cell responses. Cancer Res. 64, 5839-5849.

Roytblat, L., Rachinsky, M., Fisher, A., Greemberg, L., Shapira, Y., Douvdevani, A., and Gelman, S. 
(2000). Raised interleukin-6 levels in obese patients. Obes. Res. 8, 673-675.

Sallusto, F., and Lanzavecchia, A. (1994). Efficient presentation of soluble antigen by cultured human dendritic cells is maintained by granulocyte/macrophage colonystimulating factor plus interleukin 4 and downregulated by tumor necrosis factor alpha. J. Exp. Med. 179, 1109-1118.

Sanchez-Sanchez, N., Riol-Blanco, L., De La Rosa, G., Puig-Kroger, A., Garcia-Bordas, J., Martin, D., Longo, N., Cuadrado, A., Cabanas, C., Corbi, A. L., Sanchez-Mateos, P., and Rodriguez-Fernandez, J. L. (2004). Chemokine receptor CCR7 induces intracellular signaling that inhibits apoptosis of mature dendritic cells. Blood 104, 619-625.

Sarobe, P., Lasarte, J. J., Zabaleta, A., Arribillaga, L., Arina, A., Melero, I., Borras-Cuesta, F., and Prieto, J. (2003). Hepatitis C virus structural proteins impair dendritic cell maturation and inhibit in vivo induction of cellular immune responses. J. Virol. 77, 10862-10871.

Sathler-Avelar, R., Vitelli-Avelar, D. M., Teixeira-Carvalho, A., and Martins-Filho, O. A. (2009). Innate immunity and regulatory T-cells in human Chagas disease: what must be understood? Mem. Inst. Oswaldo Cruz 104(Suppl. 1), 246-251.

Satthaporn, S., Robins, A., Vassanasiri, W., El-Sheemy, M., Jibril, J. A., Clark, D., Valerio, D., and Eremin, O. (2004). Dendritic cells are dysfunctional in patients with operable breast cancer. Cancer Immunol. Immunother. 53, 510-518.

Savarese, E., Chae, O. W., Trowitzsch, S., Weber, G., Kastner, B., Akira, S., Wagner, H., Schmid, R. M., Bauer, S., and Krug, A. (2006). U1 small nuclear ribonucleoprotein immune complexes induce type I interferon in plasmacytoid dendritic cells through TLR7. Blood 107, 3229-3234.

Scandella, E., Men, Y., Gillessen, S., Forster, R., and Groettrup, M. (2002). Prostaglandin E2 is a key factor for CCR7 surface expression and migration of monocytederived dendritic cells. Blood 100, 1354-1361.

Scarlett, U. K., Rutkowski, M. R., Rauwerdink, A. M., Fields, J., Escovar-Fadul, X., Baird, J., Cubillos-Ruiz, J. R., Jacobs, A. C., Gonzalez, J. L., Weaver, J., Fiering, S., and Conejo-Garcia, J. R. (2012). Ovarian cancer progression is controlled by phenotypic changes in dendritic cells. J. Exp. Med. 209, 495-506.

Schreiber, R. D., Old, L. J., and Smyth, M. J. (2011). Cancer immunoediting: integrating immunity's roles in cancer suppression and promotion. Science 331, 1565-1570.

Scott, C. L., Aumeunier, A. M., and Mowat, A. M. (2011). Intestinal CD103+ dendritic cells: master regulators of tolerance? Trends Immunol. 32, 412-419.

Seifarth, C. C., Hinkmann, C., Hahn, E. G., Lohmann, T., and Harsch, I. A. (2008). Reduced frequency of peripheral dendritic cells in type 2 diabetes. Exp. Clin. Endocrinol. Diabetes 116, 162-166.

Shurin, G. V., Ouellette, C. E., and Shurin, M. R. (2012). Regulatory dendritic cells in the tumor immunoenvironment. Cancer Immunol. Immunother. 61, 223-230.

Shurin, M. R., Naiditch, H., Zhong, H., and Shurin, G. V. (2011). Regulatory dendritic cells: new targets for cancer immunotherapy. Cancer Biol. Ther. 11, 988-992.

Siegal, F. P., Kadowaki, N., Shodell, M., Fitzgerald-Bocarsly, P. A., Shah, K., Ho, S., Antonenko, S., and Liu, Y. J. (1999). The nature of the principal type 1 interferon-producing cells in human blood. Science 284, 1835-1837.

Silverstein, R. L., and Febbraio, M. (2009). CD36, a scavenger receptor involved in immunity, metabolism, angiogenesis, and behavior. Sci. Signal. 2, re3.

Sim, S. H., Ahn, Y. O., Yoon, J., Kim, T. M., Lee, S. H., Kim, D. W., and Heo, D. S. (2012). Influence of chemotherapy on nitric oxide synthase, indole-amine-2, 3dioxygenase and CD124 expression in granulocytes and monocytes of non-small cell lung cancer. Cancer Sci. 103, 155-160.

Skrzeczynska-Moncznik, J., Wawro, K., Stefanska, A., Oleszycka, E., Kulig, P., Zabel, B. A., Sulkowski, M. Kapinska-Mrowiecka, M., CzubakMacugowska, M., Butcher, E. C., and Cichy, J. (2009). Potential role of chemerin in recruitment of plasmacytoid dendritic cells to diseased skin. Biochem. Biophys. Res. Commun. 380, 323-327.

Smed-Sorensen, A., Lore, K., WaltherJallow, L., Andersson, J., and Spetz, A. L. (2004). HIV-1-infected dendritic cells up-regulate cell surface markers but fail to produce IL-12 p70 in response to CD40 ligand stimulation. Blood 104, 2810-2817.

Steinman, R. M. (2007). Lasker Basic Medical Research Award. Dendritic cells: versatile controllers of the immune system. Nat. Med. 13, 1155-1159.

Steinman, R. M., Hawiger, D., and Nussenzweig, M. C. (2003). Tolerogenic dendritic cells. Annu. Rev. Immunol. 21, 685-711.

Steinman, R. M., Inaba, K., Turley, S., Pierre, P., and Mellman, I. (1999). Antigen capture, processing, and presentation by dendritic cells: recent cell biological studies. Hum. Immunol. 60, 562-567.

Strissel, K. J., Defuria, J., Shaul, M. E., Bennett, G., Greenberg, A. S., and Obin, M. S. (2010). T-cell recruitment and Th1 polarization in adipose tissue during diet-induced obesity in C57BL/6 mice. Obesity (Silver Spring) 18, 1918-1925.

Sugimoto, H., Oda, S., Otsuki, T., Hino, T., Yoshida, T., and Shiro, Y. (2006). Crystal structure of human indoleamine 2, 3-dioxygenase: catalytic mechanism of $\mathrm{O} 2$ incorporation by a heme-containing dioxygenase. Proc. Natl. Acad. Sci. U.S.A. 103, 2611-2616.

Surendar, J., Mohan, V., Pavankumar, N., Babu, S., and Aravindhan, V. (2012). Increased levels of serum granulocyte-macrophage colonystimulating factor is associated with activated peripheral dendritic cells in type 2 diabetes subjects (CURES-99). Diabetes Technol. Ther. 14, 344-349.

Swaminathan, B., and Gerner-Smidt, P. (2007). The epidemiology of human listeriosis. Microbes Infect. 9 , 1236-1243.

Swiecki, M., and Colonna, M. (2010). Unraveling the functions of plasmacytoid dendritic cells during viral infections, autoimmunity, and tolerance. Immunol. Rev. 234, 142-162.

Taylor, M. D., Legoff, L., Harris, A., Malone, E., Allen, J. E., and Maizels, R. M. (2005). Removal of regulatory $\mathrm{T}$ cell activity reverses hyporesponsiveness and leads to filarial parasite clearance in vivo. J. Immunol. 174 4924-4933.

Terness, P., Bauer, T. M., Rose, L., Dufter, C., Watzlik, A., Simon, H., and Opelz, G. (2002). Inhibition of allogeneic $\mathrm{T}$ cell proliferation by indoleamine 2, 3-dioxygenaseexpressing dendritic cells: mediation of suppression by tryptophan metabolites. J. Exp. Med. 196, 447-457.

Tilton, J. C., Manion, M. M., Luskin, M. R., Johnson, A. J., Patamawenu, A. A., Hallahan, C. W., CoglianoShutta, N. A., Mican, J. M., Davey, R. T., Jr., Kottilil, S., Lifson, J. D., Metcalf, J. A., Lempicki, R. A., and Connors, M. (2008). Human immunodeficiency virus viremia induces plasmacytoid dendritic cell activation in vivo and diminished alpha interferon production in vitro. J. Virol. 82, 3997-4006.

Tjomsland, V., Sandstrom, P., Spangeus, A., Messmer, D., Emilsson, J., Falkmer, U., Falkmer, S., Magnusson, K. E., Borch, K., and Larsson, M. (2010). Pancreatic adenocarcinoma exerts systemic effects on the peripheral blood myeloid and plasmacytoid dendritic cells: an indicator of disease severity? BMC Cancer 10, 87.

Toossi, Z., Sedor, J. R., Lapurga, J. P., Ondash, R. J., and Ellner, J. J. (1990). Expression of functional interleukin 2 receptors by peripheral blood monocytes from patients with active pulmonary tuberculosis. J. Clin. Invest. 85, 1777-1784.

Troy, A., Davidson, P., Atkinson, C., and Hart, D. (1998). Phenotypic characterisation of the dendritic cell infiltrate in prostate cancer. J. Urol. 160, 214-219.

Tu, Z., Hamalainen-Laanaya, H. K., Nishitani, C., Kuroki, Y., Crispe, I. N., and Orloff, M. S. (2012). HCV core and NS3 proteins manipulate human blood-derived dendritic cell development and promote Th 17 differentiation. Int. Immunol. 24, 97-106.

Ueno, H., Klechevsky, E., Morita, R., Aspord, C., Cao, T., Matsui, T., Di Pucchio, T., Connolly, J., Fay, J. W., Pascual, V., Palucka, A. K., and Banchereau, J. (2007). Dendritic cell subsets in health and disease. Immunol. Rev. 219, 118-142.

Van Bilsen, J. H., Van Dongen, H., Lard, L. R., Van Der Voort, E I., Elferink, D. G., Bakker, A. M., Miltenburg, A. M., Huizinga, T. W., De Vries, R. R., and Toes, R. E. (2004). Functional regulatory immune responses against human cartilage glycoprotein-39 in health vs. proinflammatory responses in rheumatoid arthritis. Proc. Natl. Acad. Sci. U.S.A. 101, 17180-17185.

Vermi, W., Bonecchi, R., Facchetti, F., Bianchi, D., Sozzani, S., Festa, S., Berenzi, A., Cella, M., and Colonna, M. (2003). Recruitment of immature plasmacytoid dendritic cells (plasmacytoid monocytes) and myeloid dendritic cells in primary cutaneous melanomas. J. Pathol. 200, 255-268.

Villadangos, J. A., and Schnorrer, P. (2007). Intrinsic and cooperative antigen-presenting functions of dendritic-cell subsets in vivo. Nat. Rev. Immunol. 7, 543-555.

Vinuesa, C. G., Linterman, M. A., Goodnow, C. C., and Randall, K. L. 
(2010). T cells and follicular dendritic cells in germinal center B-cell formation and selection. Immunol. Rev. 237, 72-89.

Von Bergwelt-Baildon, M. S., Popov, A., Saric, T., Chemnitz, J., Classen, S., Stoffel, M. S., Fiore, F., Roth, U., Beyer, M., Debey, S., Wickenhauser, C., Hanisch, F. G., and Schultze, J. L. (2006). CD25 and indoleamine 2,3-dioxygenase are up-regulated by prostaglandin E2 and expressed by tumor-associated dendritic cells in vivo: additional mechanisms of T-cell inhibition. Blood 108, 228-237.

Watkins, S. K., Zhu, Z., Riboldi, E., Shafer-Weaver, K. A., Stagliano, K. E., Sklavos, M. M., Ambs, S., Yagita, H., and Hurwitz, A. A. (2011). FOXO3 programs tumor-associated DCs to become tolerogenic in human and murine prostate cancer. J. Clin. Invest. 121, 1361-1372.

Weatherill, A. R., Lee, J. Y., Zhao, L., Lemay, D. G., Youn, H. S., and Hwang, D. H. (2005). Saturated and polyunsaturated fatty acids reciprocally modulate dendritic cell functions mediated through TLR4. J. Immunol. 174, 5390-5397.

Wellen, K. E., and Hotamisligil, G. S. (2003). Obesity-induced inflammatory changes in adipose tissue. J. Clin. Invest. 112, 1785-1788.

Williams, C. S., Mann, M., and Dubois, R. N. (1999). The role of cyclooxygenases in inflammation, cancer, and development. Oncogene 18, 7908-7916.

Wobser, M., Voigt, H., Houben, R., Eggert, A. O., Freiwald, M., Kaemmerer, U., Kaempgen, E., Schrama, D., and Becker, J. C. (2007). Dendritic cell based antitumor vaccination: impact of functional indoleamine 2, 3-dioxygenase expression. Cancer Immunol. Immunother. 56, 1017-1024.

Yamamoto, S., and Hayaishi, O. (1967) Tryptophan pyrrolase of rabbit intestine. D- and L-tryptophancleaving enzyme or enzymes. J. Biol. Chem. 242, 5260-5266.

Yan, B., Ye, S., Chen, G., Kuang, M., Shen, N., and Chen, S. (2008). Dysfunctional CD4+, CD25+ regulatory $\mathrm{T}$ cells in untreated active systemic lupus erythematosus secondary to interferon-alphaproducing antigen-presenting cells. Arthritis Rheum. 58, 801-812.

Yang, L., and Carbone, D. P. (2004). Tumor-host immune interactions and dendritic cell dysfunction. Adv. Cancer Res. 92, 13-27.

Yu, H., Huang, H., Xiang, J., Babiuk, L. A., and Van Drunen Littel-Van Den Hurk, S. (2006). Dendritic cells pulsed with hepatitis C virus NS3 protein induce immune responses and protection from infection with recombinant vaccinia virus expressing NS3. J. Gen. Virol. 87, 1-10.

Zhang, M., Ko, K. H., Lam, Q. L., Lo, C. K., Srivastava, G., Zheng, B., Lau, Y. L., and Lu, L. (2005). Expression and function of TNF family member B cell-activating factor in the development of autoimmune arthritis. Int. Immunol. 17, 1081-1092.

Zhang, Y., Liu, S., Yu, Y., Zhang, T., Liu, J., Shen, Q., and Cao, X (2011). Immune complex enhances tolerogenecity of immature dendritic cells via FcgammaRIIb and promotes FcgammaRIIboverexpressing dendritic cells to attenuate lupus. Eur. J. Immunol. 41, 1154-1164.

Zheng, X., Suzuki, M., Ichim, T. E., Zhang, X., Sun, H., Zhu, F., Shunnar, A., Garcia, B., Inman, R. D., and Min, W. (2010). Treatment of autoimmune arthritis using RNA interference-modulated dendritic cells. J. Immunol. 184, 6457-6464.

Conflict of Interest Statement: The authors declare that the research was conducted in the absence of any commercial or financial relationships that could be construed as a potential conflict of interest.

Received: 23 May 2012; paper pending published: 22 June 2012; accepted: 10 August 2012; published online: 04 September 2012.

Citation: Schmidt SV, Nino-Castro $A C$ and Schultze JL (2012) Regulatory dendritic cells: there is more than just immune activation. Front. Immun. 3:274. doi: 10.3389/fimmu.2012.00274

This article was submitted to Frontiers in Antigen Presenting Cell Biology, a specialty of Frontiers in Immunology. Copyright (c) 2012 Schmidt, NinoCastro and Schultze. This is an openaccess article distributed under the terms of the Creative Commons Attribution License, which permits use, distribution and reproduction in other forums, provided the original authors and source are credited and subject to any copyright notices concerning any third-party graphics etc. 